\title{
Western Alps geological constraints on western Tethyan reconstructions
}

\author{
G.M. STAMPFLI', G.D. BOREL 1 , R. MARCHANT ${ }^{2}$ \& J. MOSAR ${ }^{3}$ \\ 1 Institut de Géologie et Paléontologie, Université de Lausanne, \\ $\mathrm{BFSH} 2, \mathrm{CH} 1015$ Lausanne, Switzerland \\ 2 Musée de Géologie, Lausanne, BFSH2, CH 1015 Lausanne, Switzerland \\ 3 Geological Survey of Norway - NG, Leiv Eirikssons vei 39, N-7491 Trondheim, Norway \\ gerard.stampfli@igp.unil.ch
}

\begin{abstract}
Reconstructions of the Tethyan realm have been a matter of debate for a long time. Controversies spring usually from a lack of well constrained geological data which can be interpreted in different ways, or, from a lack of constraints on the plate tectonics framework. The western Alps region tends to escape these shortcomings due to a wealth of geological data regarding for examples the rifting and spreading of the Alpine Tethys and its closure, the formation of the Alpine orogenic wedge and accompanying foreland basins, through precise datation of these many events. The larger plate tectonic framework is also well constrained through precise positioning, at least since the Jurassic, of the main plates surrounding the western Alpine Tethys domain, such as the European and African plates, but also the Iberic and Adria micro-plates and the Alboran fragments. Therefore, the Western Alps and surrounding regions represent a key-stone for the western Tethys reconstruction. A detail account of the geological evolution along a western Swiss Alps transect is presented here and confronted to the plate tectonic models derived from a larger western Tethys data base.
\end{abstract}

Keywords: Western Alps, Tethys, Plate tectonics, plate reconstructions, Alpine orogen, collision, rifting, Mesozoic, Cenozoic.

\section{Introduction}

The complexity of a mountain belt is often regarded as directly related to a complex paleogeography, when actually it is often due to a complex structural history. In the western Alps, after a century and a half of detailed structural work, the general nappe framework is now well understood and a common structural model accepted by most alpine geologists. However, its palaeogeography is still a matter of debate, and very often, complex schemes are presented, with multi-oceans plate tectonic models incorporating micro-continents corresponding to present day very tiny crustal blocks. We have shown that such models do not correspond to a certain simple plate tectonic reality, which can be deduced from large scale reconstructions using all available data, and well constrained by magnetic anomalies from the Atlantic (Stampfli et al., 2001a; Stampfli et al., 1998).

We want to sum up here the main geological constraints coming from the western Alps sector and their bearing on the present plate tectonic models of the western Tethyan region, representing a key stone in the global reconstructions we developed these past ten years (Stampfli and Pillevuit, 1993; Stampfli, 1996; 2000; Stampfli et al., 1991; 1998; 2001a). We are presenting here a geological account of major geodynamic events which can be recognised mainly on a western Swiss Alps transect and the discussion is enlarged to surrounding Alpine areas. We are concentrating on the Alpine cycle only, from the opening of the Alpine Tethys in Early Jurassic time to its closure during the Tertiary; the pre-Variscan (von Raumer et al., 2002), Variscan (Stampfli et al., 2002b) and
Cimmerian (Stampfli et al., 2002a) cycles have been recently treated in separate papers.

Part of this material was presented in a geological guide book of the western Alps, during the second field meeting of the IGCP 453 project (collisional orogen) in September 2001 in Switzerland (Stampfli, 2001), and represent a largely revised version of ideas presented in Stampfli et al. (1998).

\section{Geological background of the western Alps}

\section{Introduction}

The onset of the Alpine cycle proper could be placed when the Alpine Tethys ocean opened, i.e. in Early to Middle Jurassic time (Favre and Stampfli, 1992; Manatschal, 1995; Froitzheim and Manatschal 1996; Bill et al., 1997), following the opening of the Central Atlantic ocean (Steiner et al., 1998). This is a fundamental difference between Alpine geology s.str. and Tethyan geology s.l., or between the Alpine orogen (Alps and Carpathes) and the Tethysides (Dinarides-Hellenides, the Middle-East mountain belts and the Himalayas s.l.). The NeoTethys ocean, whose closure was responsible for the formation of the Tethysides orogen, actually does not directly interfere with Alpine geology s.str., and the Alpine Tethys should be regarded more as an extension of the central Atlantic ocean in the Tethyan realm rather than a branch of the large and older NeoTethys ocean (Stampfli, 2000). In that sense, the onset of the Alpine cycle could be placed in the Carnian, a period corresponding to the final closure of PaleoTethys in the Mediterranean and Middle- 
East regions (Stampfli et al., 2001a; 2002a) and to the onset of rifting in the central Atlantic-Alpine domain (Favre and Stampfli, 1992).

\section{The overall tectonic Evolution}

We can regard the western Alps as issued from an accretionary prism related to the closure of the Alpine Tethys where different geological objects, corresponding to different stages of accretion, can be recognised:

- oceanic accretionary prism of the Piemont ocean (the western Alps portion of the Alpine Tethys), including crustal elements from the former toe of the southern passive margin (lower Austroalpine elements),

- accreted material of the Briançonnais terrain derived from the Iberic plate,

- accreted material of the Valais domain, representing the toe of the European (Helvetic s.l.) passive margin

- accreted material of the former European continental margin and rim basin,(Helvetic s.str. domain).

In time, one passes from the oceanic accretionary prism to the formation of the orogenic wedge proper that we place after the detachment or delamination of the subducting slab in the Early Oligocene (e.g. Stampfli and Marchant, 1995). The resulting heat flux allowed some more units to be detached from the European continental slabs and resulted in large scale subduction of continental material (Marchant and Stampfli, 1997b) and obduction of the more external units:

-external Variscan massifs and their cover,

- molassic basin,

- Jura mountains.

To these accretionary events one has to add other tectonic processes such as the "Pyrenean" inversion phase (Late Cretaceous-Middle Eocene) that affected the Helvetic margin accompanied and followed by the Paleogene flexure event of the lower European plate (Paleocene to Miocene) in front of the tectonic wedge.

Structural units seen on a present day Alpine crosssection, as in figures 1 and 2, represent remnants of palaeogeographic units whose main bodies were subducted (more than 90\%). Each tectonic package is formed of obducted or underplated material with a geodynamic signature, which allows to replace them in their former palaeogeographic domain (i.e. rim basin, rift shoulder, passive margin, oceanic sequences, inversion basin, flexural bulge). In doing so, geodynamic markers (rift shoulders erosion, synrift deposits, denuded mantle) can be used to reconstruct the diverging phases, whereas palaeo-structures, ages of flysch deposits, of exotic terrain deposits and of metamorphism, as well as structural indicators, are used to reconstruct converging processes.

\section{The structural framework of the western Alps}

The present structural framework of the western Alps is shown in figures 1 and 2 (modified from Marchant, 1993; Marchant and Stampfli, 1997a; Marchant and Stampfli, 1997b), and are based on a structural model developed mainly by the Lausanne school (e.g Escher et al., 1997; Escher et al., 1988; Steck et al., 1997; Steck et al., 1989).
This structural model separates the Alpine belt into different structural domains shown in different patterns on the figures. They are from north to south:

\section{The Jura Mountains}

This is the most external domain, incorporated in the Alpine chain last (from 11 to $3 \mathrm{Ma}$ ). It is characterised by typical thin skin tectonic with a décollement located in Triassic evaporitic deposits. This décollement horizon runs under the Molasse basin and is rooted in the external massifs overthrust (recent developments on this domain are found in Sommaruga, 1999).

\section{The Molasse basin}

Formerly representing a flexural foreland basin, it became a piggyback basin during the Jura overthrusting. It comprises a sedimentary sequence starting with a Mesozoic cover similar to the Jura, followed by a major hiatus from Late Cretaceous to Eocene or Oligocene due to the fore bulge uplift. The Molasse deposits started in Late Oligocene and lasted until Late Miocene and are made of shallow water marine or continental deposits. It is separated in a southern deformed unit (Subalpine molasse) and a less deformed northern domain, which covered a large part of the Jura before its folding. (Burkhard and Sommaruga, 1998).

\section{The Préalpes}

This is a composite terrain consisting of elements from the European margin at the base (Ultrahelvetic, Niesen nappes), an important sedimentary sequences derived from the Briançonnais domain s.l. forming the bulk of the Préalpes (Médianes Plastiques and Rigides, Brèche nappes) and the Nappes Supérieures (Gurnigel, Simme, Gets) formerly pertaining to the oceanic accretionary prism of the Alpine Tethys. The Préalpes are therefore quite exotic and represent the exported suture of the orogen thrusted over the external crystalline massifs. For an extended bibliographic data base on the Prealps see: http://www-sst.unil.ch/research/prealps/index.htm

\section{The external massifs}

The Aiguilles Rouges crystalline massif and its parautochthonous cover represent the substratum of the Subalpine molasse. The Mesozoic sequence is more distal than the Jura sequence, but the lower part is missing (Triassic evaporites, Liassic platform). This area was a high during the Alpine Tethys rifting as a consequence of unloading to the south in the Helvetic rim basin.

The Mont Blanc crystalline massif and its cover the Morcles nappe, represent the northern part of the Helvetic domain. Those crystalline massifs represent the Variscan basement of the northern fringe of the orogen. They are made of metamorphic rocks in amphibolitic facies, PermoCarboniferous clastics and Permo-Carboniferous granitoids.

\section{The Helvetic nappes}

This classical domain of the Swiss Alps (Masson et al., 1980) consists of the Morcles (Doldenhorn), Ardon, Diablerets and Wildhorn nappes. The first two where deposited on the Mont Blanc massif, the décollement level being generally the Toarcio-Aalenian shales. The Mesozoic sequence of these nappes is different from the Jura-parautochthonous sequence. The Lias-Dogger 


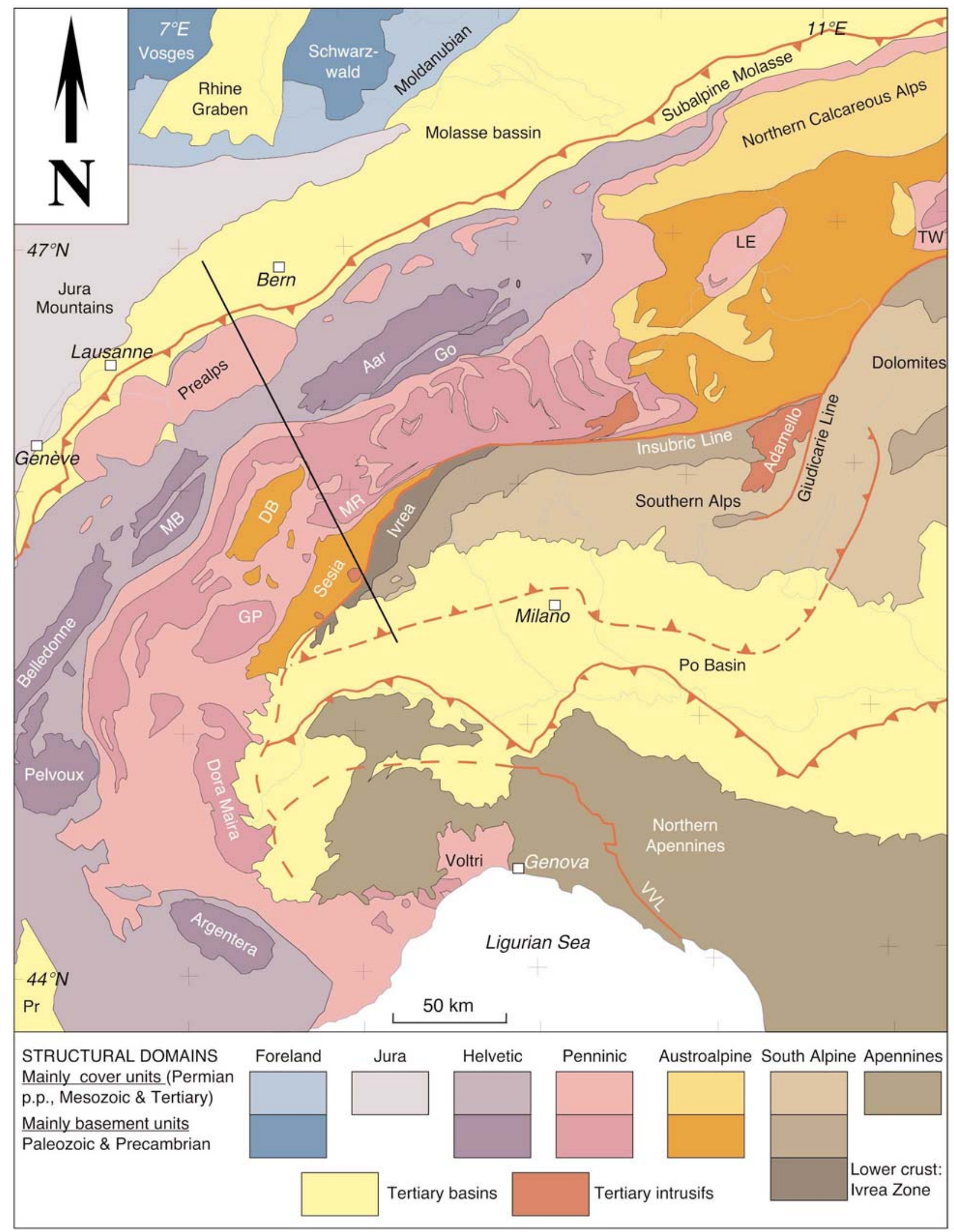

Figure 1. Tectonic map of the Western Alps (modified from Berthelsen, 1992b). Ao = Adamello intrusions; DB = Dent Blanche nappe; Go = Gotthard massif; GP = Grand Paradis massif; LE = Lower Engadine window; MB = Mont Blanc massif; MR = Monte Rosa nappe; $\mathrm{Pr}=\mathrm{Provence}$ basin; $\mathrm{TW}=$ Tauern window; $\mathrm{VVL}=$ Villalvernia-Varzi-Levanto line. 


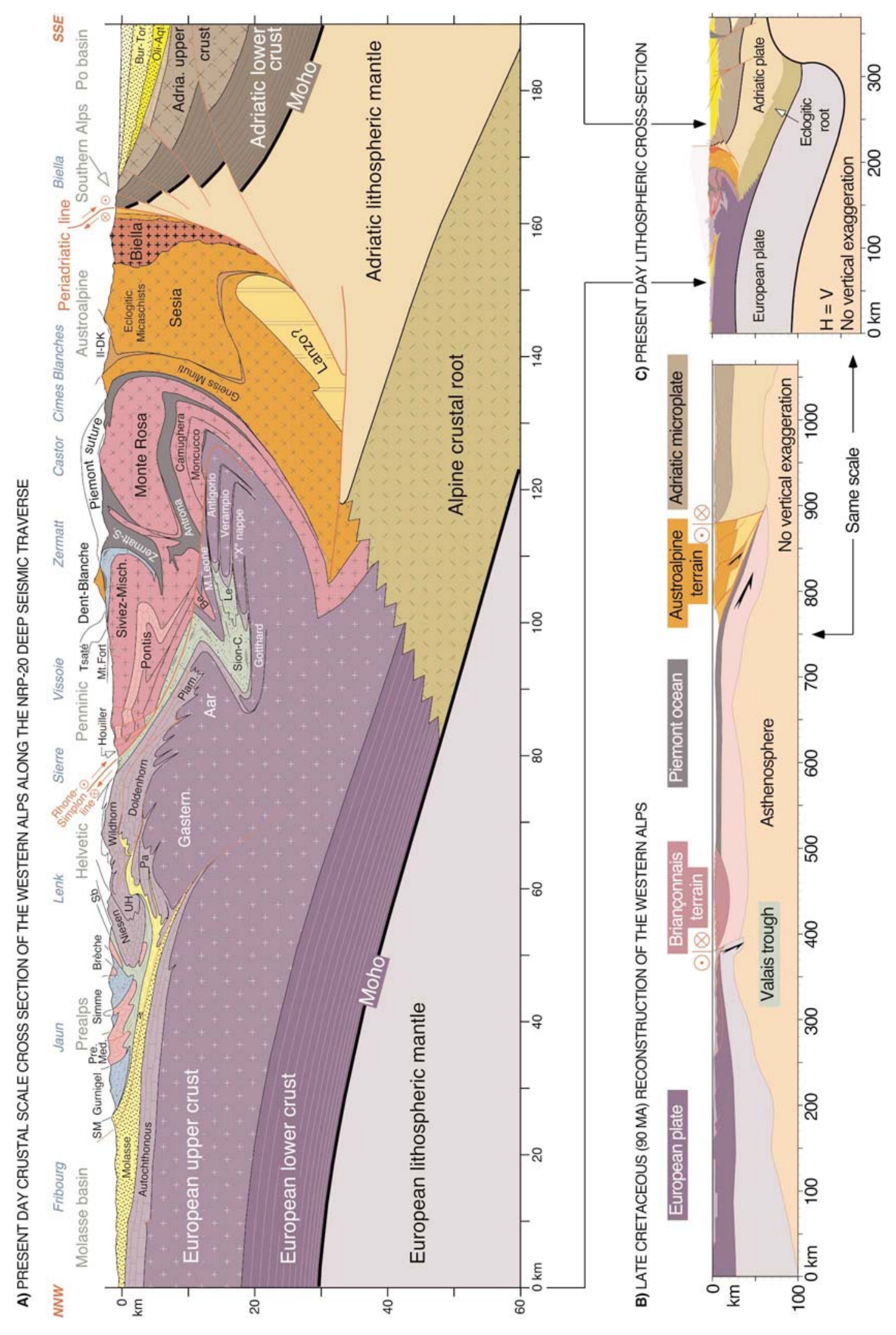

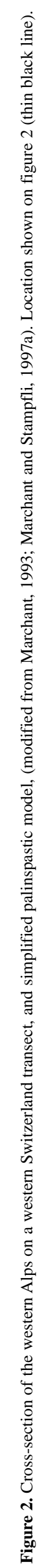


sequence is influenced by crustal extension which resulted in the formation of the Helvetic rim-basin to the north of the Piemont rift shoulder. The Late Jurassic and Cretaceous sequence is marked by the progradation of a carbonate platform which never succeeded filling-up the Wildhorn basin and never reached the distal rifted Helvetic margin. Major uplift took place in Late Cretaceous and Paleocene time, related to the flexure of the European margin and the Pyrenean movements. A general transgression of the fore-bulge took place during the Eocene forming a new carbonate platform which gave way progressively to the flysch deposits (see figure 16). In France the Helvetic domain is called Dauphinois.

\section{The Ultrahelvetic nappes}

These nappes are found in several locations: first as a sole of the Préalpes massif; as klippen on the Helvetic nappes and in the Helvetic root zone. They represent distal portion of the southern part of the Helvetic rim basin, the rift shoulder area and the attenuated northern rifted margin of the Alpine Tethys. The Mesozoic sequence contains Triassic evaporites, a Liassic-Dogger platform sequence and a condensed, starved Late Jurassic-Cretaceous pelagic sequence.

\section{The lower Penninic nappes}

These highly metamorphic, mainly crustal nappes represent the former rift shoulder and syn-rift domains of the European margin. They consist of the Verampio, Antigorio and Monte Leone crystalline nappes with incomplete Mesozoic cover and the Lebendun nappe composed of thick clastic deposits attributed now to former syn-rift deposits (Spring et al., 1992). Some Ultrahelvetic nappes and the Niesen nappe were certainly partially deposited on this lower Penninic nappes domain. The Niesen nappe contains Jurassic syn-rift deposits at its base and then inversion related Late Cretaceous clastics.

\section{The Valais suture zone}

Coming from this relatively thin structural domain we find mélanges like the Submédianes zone of mixed elements of the Valais trough and distal Helvetic margin origin, found now as separate elements in the Préalpes. The distal clastics and pelagic Cretaceous deposits of the Sion-Courmayeur zone would have been deposited on the Helvetic distal margin and the ocean-continent transition zone (the Valais trough). Denuded continental mantle units like the Geisspfad massifs represent this transition found within the lower Penninic nappes named Valaisan domain in the paleogeographic nomenclature. The infraMoncucco ophiolitic zone represents Piémont oceanic crust trapped between the Helvetic margin and the Briançonnais exotic terrain. This suture is better expressed in central Switzerland where the Bündnerschiefer accretionary prism (between the European Adula nappe and the Briançonnais Tambo nappe; Schmid et al., 1990) contains a fair amount of Piemont MORB relicts. A Late Eocene mélange is found between the Valais zone and the Briançonnais domain (Pierre Avoi unit, Bagnoud et al. 1998). Generally speaking this domain is poorly dated.

\section{The middle Penninic nappes}

This domain belonged formerly to the Briançonnais terrain and is exotic in regard to the more external units, an observation already made by Schardt at the end of the 19th century (Masson, 1976). It is made of the Zone Houillère (Permo-Carboniferous graben), the Pontis basement nappe on which the Préalpes Médianes Plastiques were deposited, the Siviez-Mischabel basement nappes on which the Préalpes Médianes Rigides were deposited. These basement nappes are made of Variscan polymetamorphic rocks with a sedimentary cover including Permo-Carboniferous clastic deposits transgressed by a Mesozoic sequence, most of it detached from its substratum and transported to the north in the Préalpes region. The Préalpes Médianes domain was a rim basin of the European margin, located north of the rift shoulder. It can be regarded as a lateral southwestern equivalent of the Helvetic rim basin and was formerly located south of France. The duplication of these rim basin/rift shoulder elements on a western Alpine crosssection is a fundamental feature of the western Alps.

In the more internal part of the middle Penninic units are found the Mont-Fort nappe (located in the Valais) and Brèche nappe (located in the Préalpes), representing the former syn-rift part of the European margin on the Briançonnais transect. This type of unit are sometime called pre-Piemontais units as they represent the transition to the Piemont ocean (the western Alps part of the Alpine Tethys ocean, its Italian part being referred to as Ligurian, its Austrian equivalent being often referred to as Penninic ocean)

\section{The upper Penninic nappes}

This domain represents the suture zone of the Alpine Tethys (Piemont suture). It is made of a large scale accretionary mélange comprising the former oceanic accretionary wedge of the Alpine Tethys (the Tsaté nappe, with relicts of blue schist metamorphism), from which the non-metamorphic Nappes Supérieures are derived (the Gurnigel, Simme and Gets nappes of the Préalpes domain) and a zone of (eo-Alpine?) Alpine HP-LT metamorphism made of mixed oceanic and continental crustal units (Zermatt-Saas Fee and Antrona ophiolitic nappes and the Internal Massifs).

The eclogitic internal massif (Mont Rose, Gran Paradiso, Dora Maira) are continental exotic blocks of disputed origin (lower Austroalpine, Briançonnais or even Helvetic e.g. Froitzheim, 2001), underplated in the accretionary complex, sometimes at great depth (over 100 $\mathrm{km}$ for UHP Dora-Maira eclogites) and subsequently mixed with oceanic elements in a westward tectonic escape movement during their extrusion.

\section{The Austroalpine nappes}

These mainly crustal nappes in western Switzerland represent the former southern passive margin of the Alpine Tethys. The thinned part of the margin was probably subducted and partially underplated to form the exotic elements now found in the Piemont suture zone (? parts of the Internal Massifs). The rest of this domain (the Dent Blanche klippe and Sesia zone) formed the former backstop of the Tsaté accretionary prism and was partly overthrusted by the Adriatic micro-continent (South Alpine units). Subsequently this overthrust was largely deformed by the back-folding of the orogenic wedge and 
the indentation of the Adriatic plate. Major lateral movement of these units took place during the Late Cretaceous and they can be regarded as displaced terrains in regard to Adria. The Sesia zone records Late Cretaceous HP-LT metamorphism.

\section{The South Alpine domain}

This domain represents the northern margin of the Adriatic microplate, its northeastern part (Canavese) collided with the displaced Austroalpine elements during their westward escape in Late Cretaceous. So here too, we have a potential duplication of the southern marginal domain and a possibility of trapped oceanic rocks between the Canavese and Sesia units. The Adriatic lower crust is outcropping in the Ivrea zone which forms the present day back-stop of the Western Alps orogen. This back stop was strongly affected by two events: the back folding of the internal units since Oligocene and the emplacement of the peri-Adriatic plutonic rocks derived from the detachmentdelamination of the Tethyan slab more or less at the same time.

\section{The geodynamic framework of the western Alps}

\section{The plate tectonics of the western Tethyan regions}

The reconstructions shown in figure 4 to 9 are based on a tight pre break-up Permian fit (fig 3) as well as magnetic anomalies from the Central Atlantic. They have been constructed in a continuous effort to apply plate tectonic concept to palinspatic model of the western Tethys, moving away from pure continental drift model not constrained by plate limits (Stampfli and Borel, 2002). The constraints and data bases used in that project can be found in the literature cited above in the introduction. This plate model takes into account the likelihood of a Late Paleozoic rifting and sea-floor spreading of the eastern Mediterranean basin (Stampfli et al., 2001c). This opening would be concomitant with the opening of the NeoTethys and the northward drifting of the Cimmerian continents since late Early Permian. This model considers also a late closure of the PaleoTethys (Middle to Late Triassic) on a Greek and Turkish transect of the Tethyan realm(Stampfli et al., 2002a), accompanied by the opening of back-arc basins (fig. 4, Meliata, Maliac and Pindos back-arc basins).

\section{The Apulia Adria problem}

A review of palaeomagnetic data regarding the Alpine and Mediterranean area suggests that the method cannot sort out paleopositions of small terrains having suffered small amounts of displacement. It is possible, however, to show that the Apulian plate s.l.(Italy) suffered relatively little rotation in regard to Africa since Triassic (e.g. Channell, 1992; 1996). This leaves open the question of an Apulian plate being an African promontory or not. Also, the continuity between the active subduction zone under Greece and the outer Dinarides (de Jonge et al., 1994; Wortel and Spakman, 1992) shows that there is a possible plate limit between Apulia s.l. and the autochthonous of Greece.
Together with major problems concerning the reassembling of micro-plates in a pre-break-up position (fig. $3 \& 4$ ), this leads us to consider that the Apulian plate s.l. is most likely cut into two pieces, an Apulian plate s.str. to the south and an Adriatic plate s.str. to the north. The Apulian part is definitely an African promontory from Middle Triassic to recent times and represents the eastern most Cimmerian element detached from Gondwana in

Figures 3 to 9 (Following pages). Early Permian to Late Cretaceous reconstructions of the western Tethyan realm, (modified from Stampfli et al., 2001a; Stampfli and Borel, 2002), rift zone are shown in greenish color, foreland in orange color. Legend: AA, Austro-Alpin; Ab, Alboran; Ad, Adria s.str.; Ae, Abadeh; Ag, Aladag; Ah, Agh-Darband; Ai, Argolis ophiolites; Aj, Ajat; Al, Alborz; An, Antalya; Ap, Apulia s.str.; AP, Aspromonte, Peloritani; Ar, Arna accretionary complex; As, Apusenisouth, ophiolites; At, Attika; AT, Alpine Tethys; Av, Arvi ; Ba, Balkanides, externat ; Bc, Biscay, Gascogne; Bd, Beydaghlari; Be, Betic; Bh, Bihar; Bi, Ba'id; Bk, Bolkardag; Bn, Bernina; Br, Briançonnais; Bs, Bisitoun seamount; Bt, Bator-Szarvasko ophiolites; Bu, Bucovinian; Bü, Bükk; Bv, Budva; By, Beyshehir; Bz, Beykoz basin; Ca, Calabride; cA, central Afganistan; cB, central Bosnia; Cc, Caucasus s.l.; cI, central Iberia; Ci, Ciotat flysch; Co, Codru; Cn, Carnic-Julian; CP, CalabriaPeloritani; cR, circum-Rhodope; Cv, Canavese; Da, Dacides; Db, Dent Blanche; DD, Dniepr-Donetz rift; Dg, Denizgören ophiolite (IP suture); DH, Dinarides-Hellenides; Do, Dobrogea; Dr, Drina-Ivanjica; Ds, Drimos ophiolites; Du, Durmitor; Dz, Dzirula; eP, east Pontides; Er, Eratosthen; Fa, Fatric; Fr, Farah basin; gC, great Caucasus; Gd, Geydag; Ge, Gemeric; GS, Gory-Sovie; GT, Gavrovo-Tripolitza; Gt, Getic; Gü, Gümüshane; hA, high-Atlas; Ha, Hadim; He, Helvetic rim basin; Hg, Huglu; hK, high karst; Hr, Hronicum; Hy, Hydra; IA, Izmir-Ankara ocean; Ig, Igal trough; Io, Ionian; iP, intra-Pontides; Is, Istanbul; Ja, Jadar ; Jf, Jeffara rift; Jo, Jolfa; Jv, Juvavic; Ka, Kalnic; Kb, Karaburun; Kd, Kopet-Dagh ; Kf, Kotel flysch; Ki, Kirshehir; Kk, Karakaya forearc; Ko, Korab; KS, Kotel-Stranja rift; KT, Karakum-Turan; Ku, Kura; Kü, Küre ocean; Ky, Kabylies; La, Lagonegro; Lg, Longobucco; 1A, lower Austroalpine; Lg, Ligerian ; Li, Ligurian; Lo, Lombardian; Ls, Lusitanian; Lu, Lut ; Ly, Lycian ophiolitic complex; mA, middle Atlas; Ma, Mani; Mc, Maliac rift/ocean; Md, Mozdak; MD, Moldanubian; Me, Meliata rift/ocean; Mf, Misfah seamount; Mi, Mirdita autochton; Mk, Mangyshlak rift; Mm, Mamonia accretionary complex; MM, MegumaMeseta ; Mn, Menderes; Mo, Moesia; Mr, Mrzlevodice fore-arc; Ms, Meseta; MS, Margna-Sella; Mt, Monte Amiata fore-arc; Mz, Munzur dag; nC, north Caspian; NCA, North Calcareous Alps; Ni, Nilüfer seamount; Nr, Neyriz seamount; Ns, Niesen flysch; Ot, Othrys-Evia ophiolites; Pa, Panormides; Pd, Pindos rift/ocean; Pe, Penninic; Pi, Piemontais; Pk, Paikon intra oceanic arc; Pl, Pelagonian ; Pm, Palmyra rift; Pn, Pienniny rift; Px, Paxi; Py, Pyrenean rift; Qa, Qamar; Qi, Qilian; Qn, Qinling north; Qs, Qinling south; Rf, Rif, external; Rh, Rhodope; Ri, Rif, internal; Ru, Rustaq seamount; Rw, Ruwaydah seamount; sA, south Alpine; sB, sub-Betic rim basin; Sc, Scythian platform; sC, south Caspian basin; Sd, Srednogorie rift-arc; Se, Sesia (western Austroalpine); Sh, Shemshak basin; Si, Sicanian; Sj, Strandja; Sk, Sakarya; sK, south-Karawanken fore arc; S1, Slavonia; Sm, Silicicum; SM, Serbo-Macedonian; Sr, Severin ophiolites; SS, Sanandaj-Sirjan ; sT, south-Tibet; St, Sitia; Su, Sumeini; Sv, Svanetia rift; Ta, Taurus, s.1.; Tb, Tabas; TB, Tirolic-Bavaric; tC, Transcaucasus; TD, Trans-Danubian; To, Talea Ori; Tr, Turan; Tt, Tatric; Tu, Tuscan ; Tv, Tavas+Tavas seamount; Ty Tyros fore arc; Tz, Tizia; uJ, upper Juvavic; Va, Valais trough; Ve, Veporic; Vo, Vourinos (Pindos) ophiolites; Vr, Vardar ocean; wC, western-Crete (Phyl-Qrtz) accr. cpl; WC, West-Carpathian; Ya, Yazd 

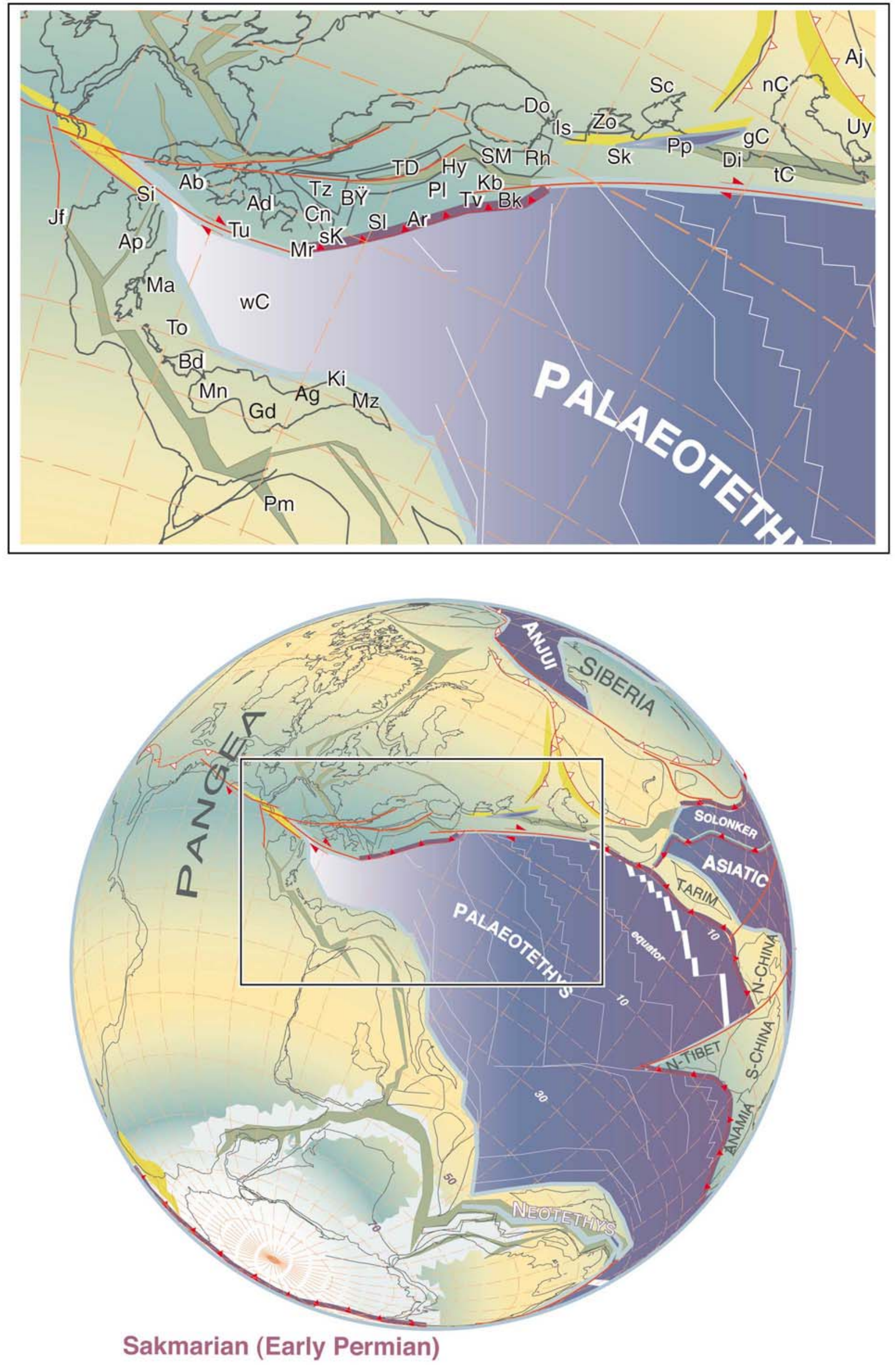

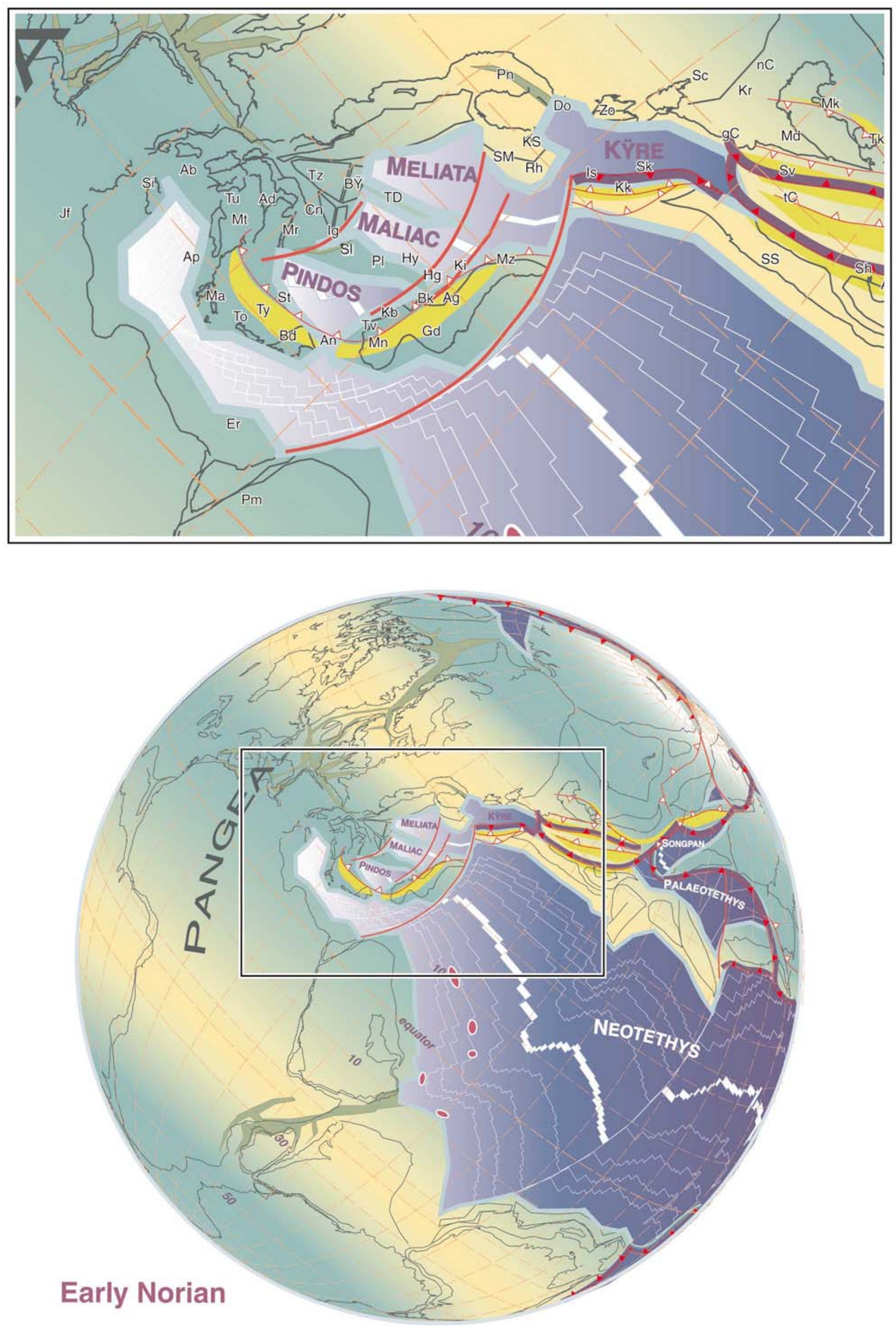

Figure 4. 

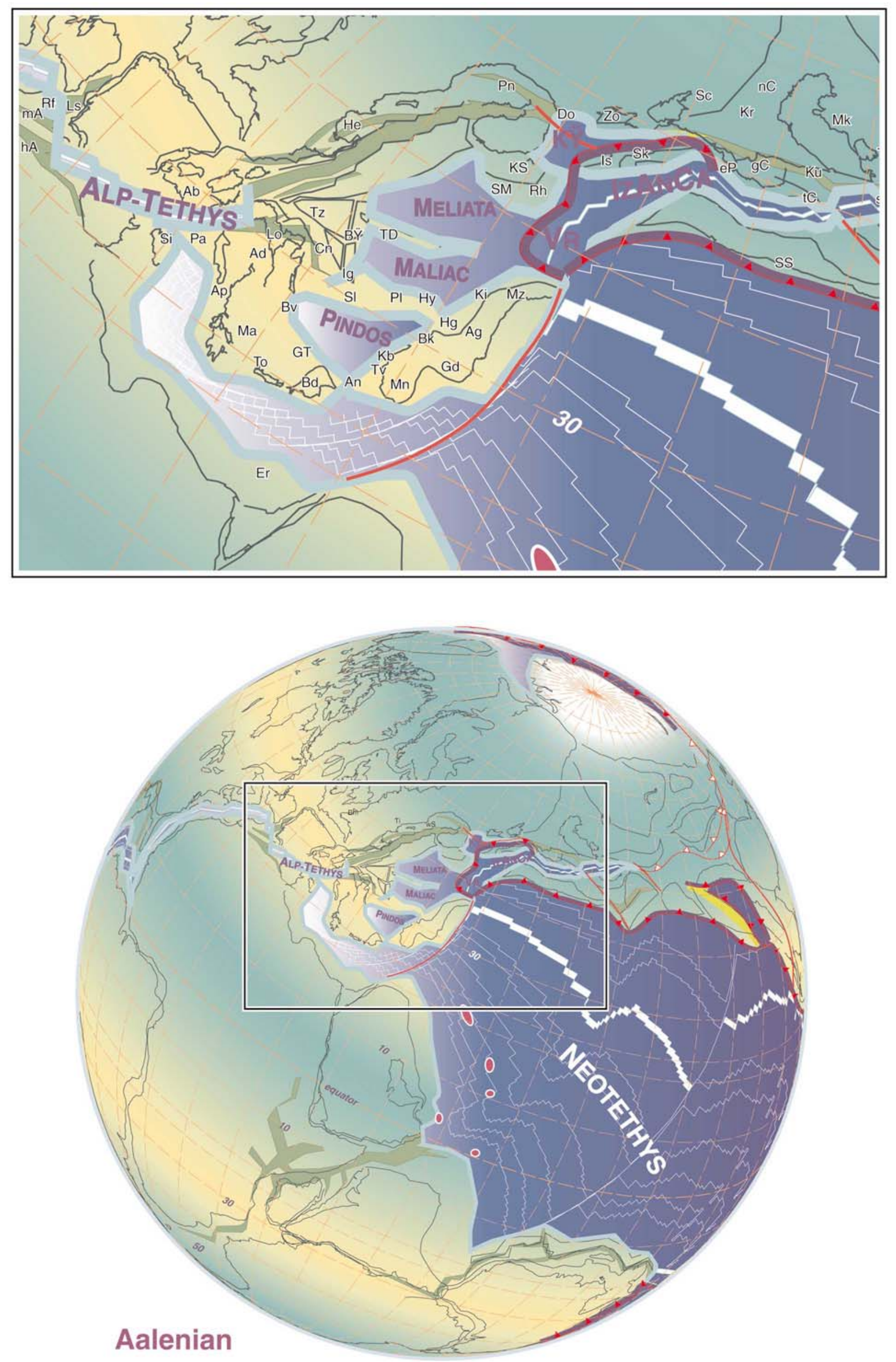

Figure 5. 
Late Permian times during the opening of the East Mediterranean - Neotethys, basin. The Adriatic and Apulian plates were welded in an eo-Cimmerian collision phase during the Triassic and were part of the African plate until Early Cretaceous. Then, Adria started a left-lateral displacement to reach its final position in the Miocene as a separate entity, it was partially subducted under the Dinarides and the Apennines.

The Adriatic plate can therefore be considered as a displaced terrain like most large tectonic units from the former southern margin of the Alpine Tethys - the Austroalpine, Carpathians and Tisia composite terrains. Unlike Adria and Tisia which are still rooted in the lithosphere, the Austroalpine and Carpathian composite terrains were decoupled at upper crustal level and incorporated in the orogenic wedge. Their composite nature comes from the fact that they record the closure not only of the Alpine Tethys but also of older oceanic domains such as the Meliata-Maliac and Vardar oceans.

\section{Triassic back-arc oceans of the PaleoTethys}

The exotic character of the upper Austroalpine terrain (North Calcareous Alps) and the necessity to open an oceanic area between the internal part of the Carpathian domain (Tisia) and the Austroalpine domain is now widely accepted. This Meliata-Hallstatt ocean is now better known and its different parts have been studied and dated in some details (Kozur, 1991; Haas et al., 1995). We consider the opening of this Meliaticum domain as a result of continuing subduction along the eastern part of the European margin in the Late Paleozoic (Stampfli et al., 2001b; Vavassis et al., 2000). The northward subduction of a remnant PaleoTethys induced the opening of back-arc type basins already in Carboniferous-Permian times in a general context of cordillera collapse following the accretion of the Variscan terrains in Early Carboniferous time (Ziegler and Stampfli, 2001). The back-arc spreading lasted until Late Triassic in the Mediterranean domain (Kozur, 1991; Stampfli et al., 2001b).

The Meliata rift possibly extended westward to the Ivrea zone (Zingg et al.,1990) in the Southern Alps where Permian and Triassic rifting and volcanism is well documented (e.g. Winterer and Bosellini, 1981). The Meliata rift extension in that region would have been of intracontinental type and is also possibly recorded in the Sesia nappe (Venturini, 1995). However, remnant of Meliata oceanic material and metamorphic rocks related to its closure are not present in the Western Alps. Accelarating slab roll-back, and even detachment of the PaleoTethys slab, induced a jump of the back-arc spreading, to the Maliac rift in late Middle Triassic (De Bono, 1998) then a new jump opened the Pindos in Late Triassic (Vavassis, 2001; Stampfli et al., 2002a).

During the opening of the Central-Atlantic/Alpine Tethys system the Meliata oceanic domain started subducting southward in connection with the southward subduction of the Küre basin north of Turkey (Stampfli et al., 2001b). The slab roll-back of Meliata was responsible for the opening of the Vardar back-arc basin in Middle Jurassic times, which partially obducted in Late Jurassic onto the Pelagonian micro-continent (in Greece, Bulgaria,
Yougoslavia, fig. 6; e.g. Baumgartner, 1985; De Bono, 1998).

The opening and closing of the Meliata-Maliac domain affected the whole Alpine history. First it created a generalised thermal subsidence starting in the Late Permian responsible for the large scale Triassic transgression on the Alpine regions. Then, its closure in the Late Jurassic (Kozur, 1991) affected the whole Austroalpine domain (the Austrian deformation phase) and can be seen as a major element in the onset of the closure of the Alpine Tethys itself on an Eastern Alps transect (Froitzheim et al., 1996). The southward subduction of the Meliata-Küre system is certainly responsible for the (local) southward subduction of the European slab, a unique feature in the whole Alpine s.l. system where generally the southern continents are subducted northward (Africa, Arabia, India).

\section{The Alpine Tethys rifting}

Late Triassic ages obtained from shear zones in the Southern Alps (Hunziker et al., 1992; Schmid et al., 1987) witness important transtensive events which eventually developed into the opening of the central Atlantic/Alpine Tethys ocean and the final break-up of Pangea. The areas affected by transtension and emplacement of mafic material during the Permo-Triassic became subsiding rimbasins of the Jurassic Alpine Tethys (fig. 4). This is the case for the Médianes (Subbriançonnais) and Helvetic rim basins. Paleozoic faults were also reactivated on a large scale in these domains to form shallow half-grabens (Borel, 1997). The Jurassic rifting is actually cutting in between these zones of thinned and already cold lithosphere, most likely using older structures. It has to be emphasised here that the thermal subsidence of large parts of the Alpine orogen started in Triassic time and that this subsidence is hardly disturbed in areas far enough from the Jurassic rift (Stampfli, 2000). These different subsidence behaviours can be used to sort out paleogeographic units; they also indicate the importance of the Permo-Triassic lithospheric extensional phase.

Subsidence patterns of the marginal areas of the Alpine Tethys (Borel, 1995; Loup, 1992) together with stratigraphic and sedimentological records allow to place the onset of rifting in the Sinemurian (fig. 10). Spreading in the central Atlantic is placed in the Early Toarcian (Steiner et al., 1998). The former Atlantic rift would have extended first toward the Lombardian basin, which aborted, then, the rifting jumped to the Alpine Tethys s.str. (the Liguro-Piemont Penninic ocean) where the onset of spreading is of probable Aalenian to Bajocian age. Gabbros have been dated in several areas of the Alpine Tethys, the oldest dating are usually Bajocian (e.g. Bill et al., 1997), in Corsica older ages have been found and points to a possible late Toarcian-Aalenian age (Beccaluva et al 1981). It should be emphasized here that up to 100 to $150 \mathrm{~km}$ of the nascent ocean were made of denuded continental mantle, based on comparison with the Galicia margin (e.g. Manatschal and Bernoulli, 1998; Müntener and Hermann, 2001), and, in view of the slow spreading of the ocean (Rampone and Piccardo, 2000), clear seafloor spreading was delayed in regard of the onset of 

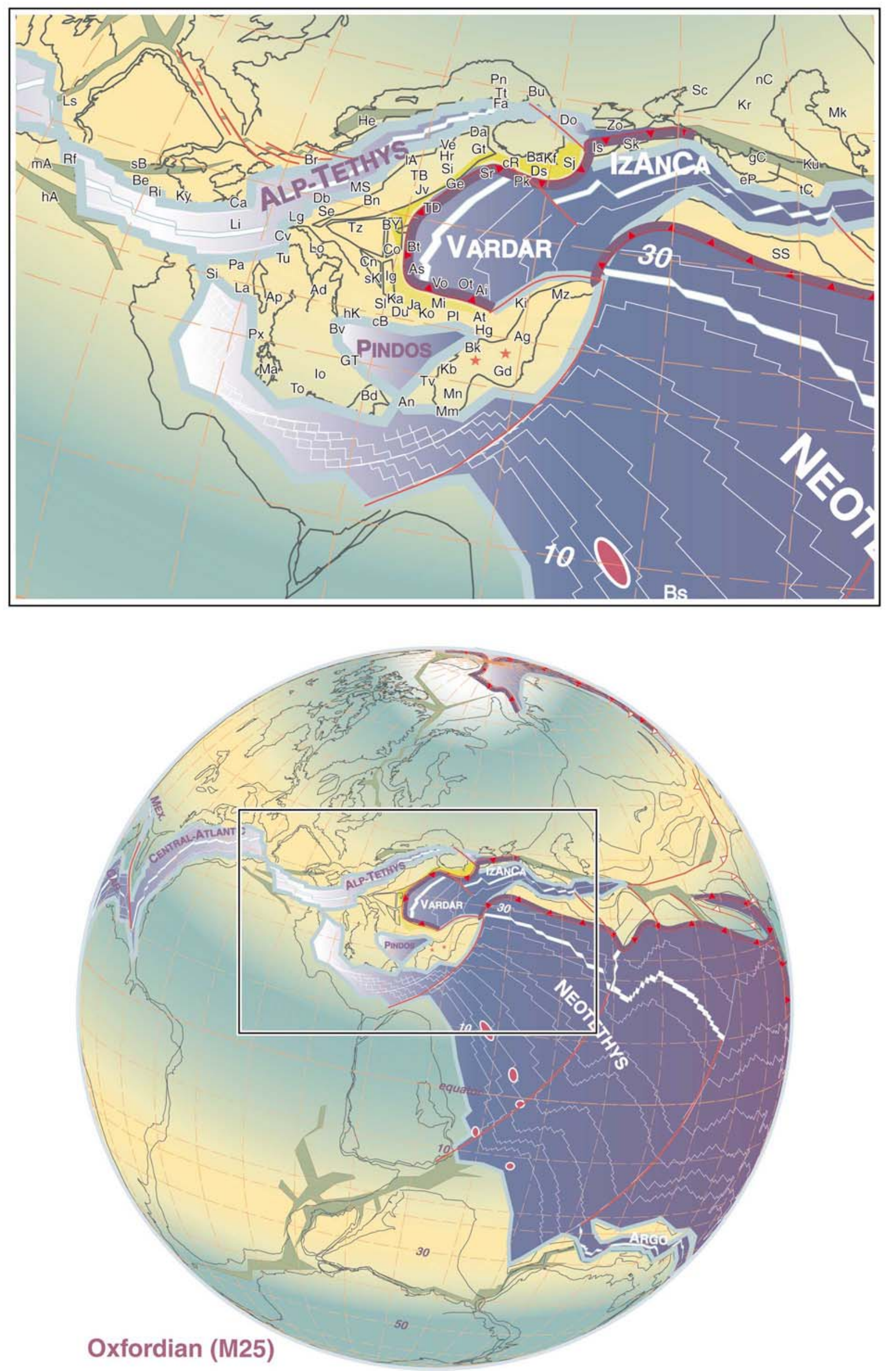

Figure 6. 

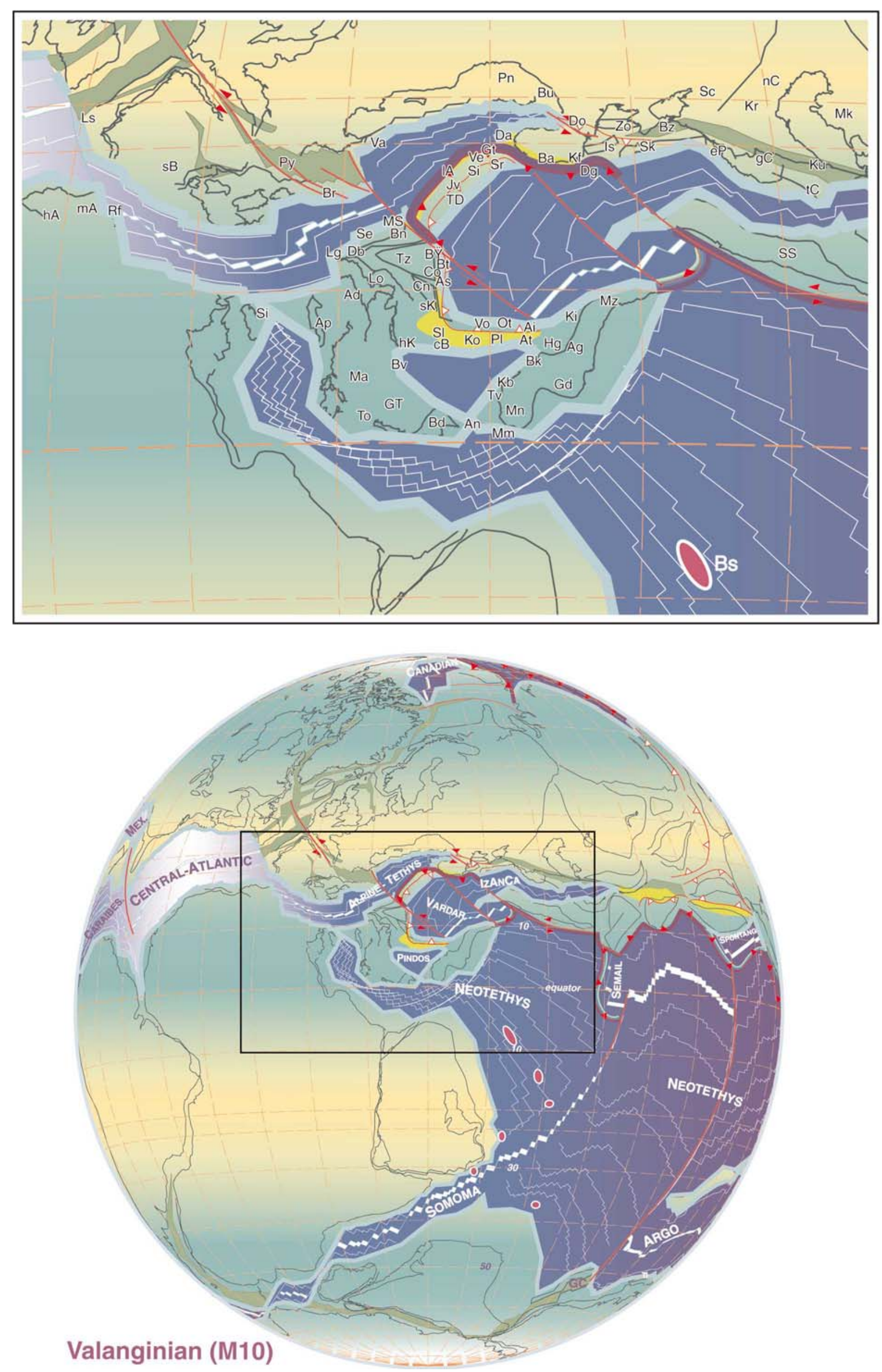

Figure 7. 

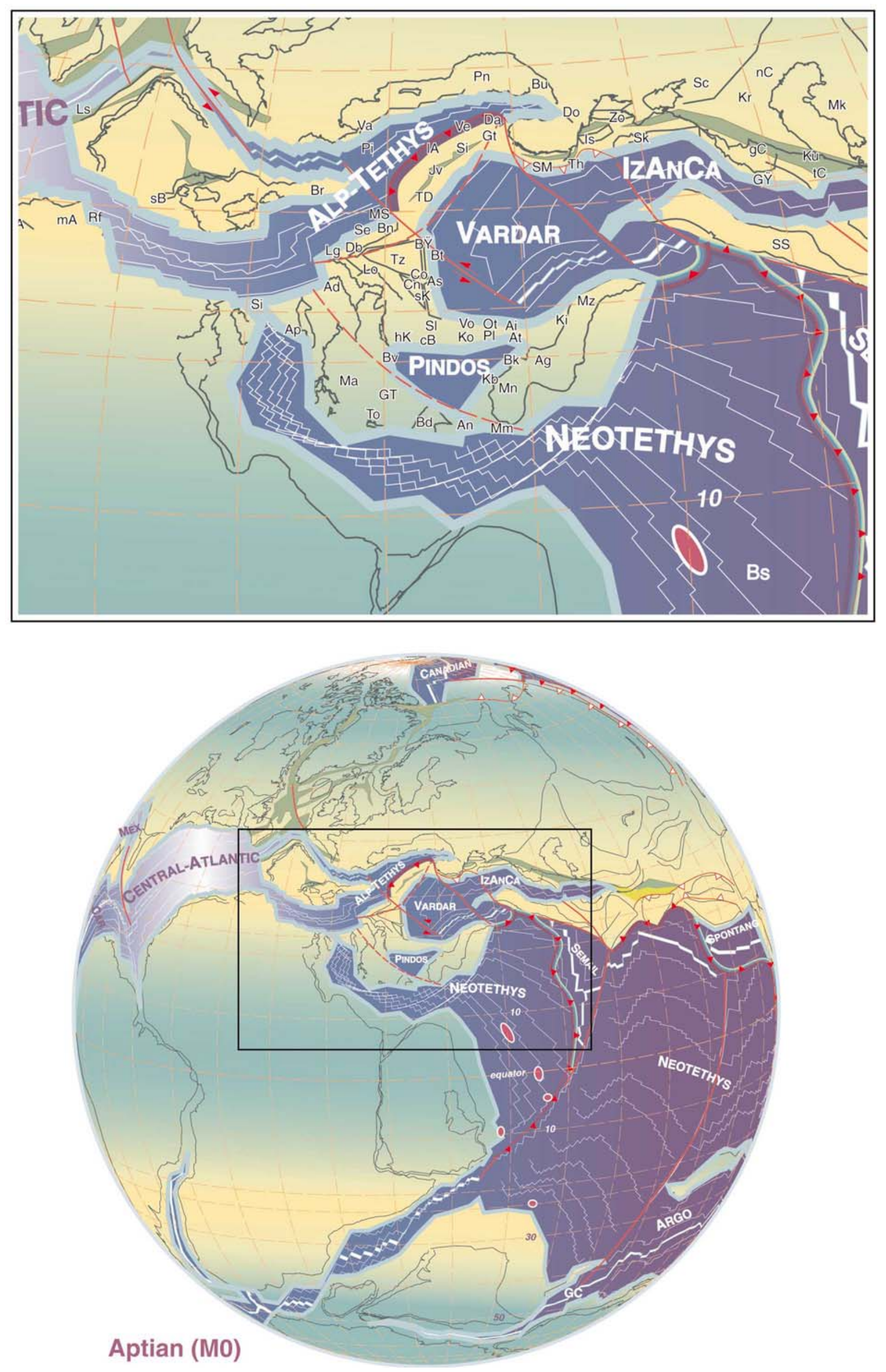

Figure 8. 
thermal subsidence which is older than Bajocian, the Bajocian sequences being generally transgressive on the rift shoulders.

\section{Rim Basins}

Thermal subsidence of the Alpine Tethys margins in the Bajocian affected large areas around the new oceanic area. The progradation of carbonate platforms toward the rift/ocean was hampered by the presence of rim basins on both sides of the Alpine Tethys in the western Alps. To the north the Helvetic-Dauphinois basin and its SW extension toward the Sub-Briançonnais rim basin, Sardinia and the Sub-Betic rim basin. To the south the Lombardian rim basin representing a clear aborted arm of the Alpine Tethys (Bertotti et al., 1993), active from Late Triassic to Early Jurassic. Progradation did not succeed infilling these rimbasins and the former rift shoulders of the Alpine Tethys (the Briançonnais and south Helvetic domains in the north and the Canavese and lower Austro-Alpine domains to the south) became drowned submarine ridges developing condensed pelagic sequences. Therefore a general phase of sediment starvation characterises the distal part of the Alpine Tethys margins and the ocean itself. However, small carbonate platforms developed for a short time (Bajocian-Oxfordian) around the rift shoulders, e.g. the Briançonnais platform (Septfontaine, 1983) and in some south Helvetic units (Lempicka-Münch, 1996). They were linked to larger platforms along the rift shoulder as found in Corsica and Sardinia, and were finally drowned in the Late Jurassic; the south Helvetic platform could never develop as a large entity and must have been made of small carbonate patches already drowned in Oxfordian times. The progradation of the Briançonnais platform took place towards the rim basin - to the north, away from the rift shoulder, so in an opposite direction of the general progradation on the European margin.

The "Valais ocean" question, and the Alps Pyrenees connection

From much, sometimes contradicting data concerning the Iberian drift (Stampfli, 1993; Stampfli et al., 1998) it can be determined that the opening of the Pyrenean rift system started in Late Jurassic times when Iberia was detached from New-Foundland. The minimal opening would be $200 \mathrm{~km}$ following the data from Malod and Mauffret (1990) or $350 \mathrm{~km}$ using the data of Sibuet and Colette (1991). Discrepancies stem from the former situation of Iberia with regard to New Foundland. The data of Srivastava et al. (1990) and of Srivastava and Verhoef (1992) allow to narrow down these differences and their proposal was applied for our model where a tight Permian fit for Pangea is used.

The portion of the Pyrenean rift between Provence and the Briançonnais was roughly parallel to the central Atlantic rift between Iberia and New Foundland (fig. 6 \& 7) and, therefore, certainly opened at the same time. The oldest magnetic anomaly in that part of the Atlantic is M0 (Hauterivian to earliest Aptian depending on the time scale...); however the sea-floor spreading is inevitably slightly older than the first clear magnetic anomaly.

In the Pyrenean region, the thermal event linked to the rising asthenosphere has been placed between $115 \mathrm{Ma}$ and
80 Ma by Montigny (1986), it is regarded as Late Albian $(\approx 100 \mathrm{Ma})$ by Peybernes (in: Debrand-Passard and Courbouleix, 1984). The Bay of Biscay opened later, together with the Aquitaine basin and the reactivation of the Iberian rift (Vergés and Garcia-Senz, 2001), during the rotation of Iberia, after the Valanginian (Moreau et al., 1992) and after the Atlantic opening between Iberia and America, therefore, in Late Aptian-Albian times; spreading there stopped in the Campanian (A33 anomaly, see figure 9). Thermal subsidence is active in the Late Cretaceous for the Pyrenees and the Gulf of Biscay region (fig. 10) where the Cenomanian is largely transgressive on the former rift shoulders (Peybernès, 1976; Peybernès and Souquet, 1984; Simo, 1986).

The major change of sedimentation in the Briançonnais domain, located on the Iberian plate, is found at the top of the Calcaires Plaquetés (Python-Dupasquier, 1990) and can be dated as Barremian. It corresponds to a general drowning and starvation phase of the area at that time. There is also a major sedimentary gap in the Albian that we relate to the thermal uplift of the Briançonnais. The Helvetic-Dauphinois margin is also affected by the Pyrenean rifting phase, clearly expressed on the subsidence curves for the Helvetic and Swiss plateau domain (fig. 10).

Obviously the timing of sea-floor spreading along this new lithospheric fracture is not synchronous, even more because the northern border of the Iberic plate in the Pyrenean portion is of transform type and, may be, never generated sea-floor spreading, the crustal attenuation however reached denudation of continental mantle (the Lherzolites of Lherz)

The "Valais trough", as recognised in the western Alps in the present days, is actually the remnant of trapped Piemont sea-floor and of the toe of the Helvetic margin (fig. 6 to 9). The "Valais ocean" (as defined in Stampfli, 1993) was located south of France and we refer to it here as the "Pyrenean ocean" to avoid the confusion between Valais ocean and Valais trough. No direct traces of this ocean have been found so far because its suture was located exactly where the Algero-Provençal ocean reopened in Oligo-Miocene times (Roca, 2001). The southern margin of the Pyrenean ocean was the Briançonnais peninsula (fig. 11), its northern margin was the Corbières-Provençal domain from the Pyrenees to the Maures-Estérel massifs. The Pyrenean margin of the Briançonnais outcrops in the Galibier region of the French Alps (Toury, 1985), well known for its Late Jurassic Brèche du Télégraphe (Kilian, 1891). Recent investigation there (Luzieux and Ferrari, 2002), showed us the development of a pull-apart type basins rapidly deepening under the CCD in Late Jurassic times and located to the north of the classic Briançonnais domain. This area developed facies different from the Swiss subBriançonnais during the Cretaceous, and is regarded as the most external sub-Briançonnais elements known so far. Its conjugate northern Provençal margin area is characterised by important erosion during the Oxfordian and the development of Albian basins deepening southward towards the "ocean", followed by inversion related basins 

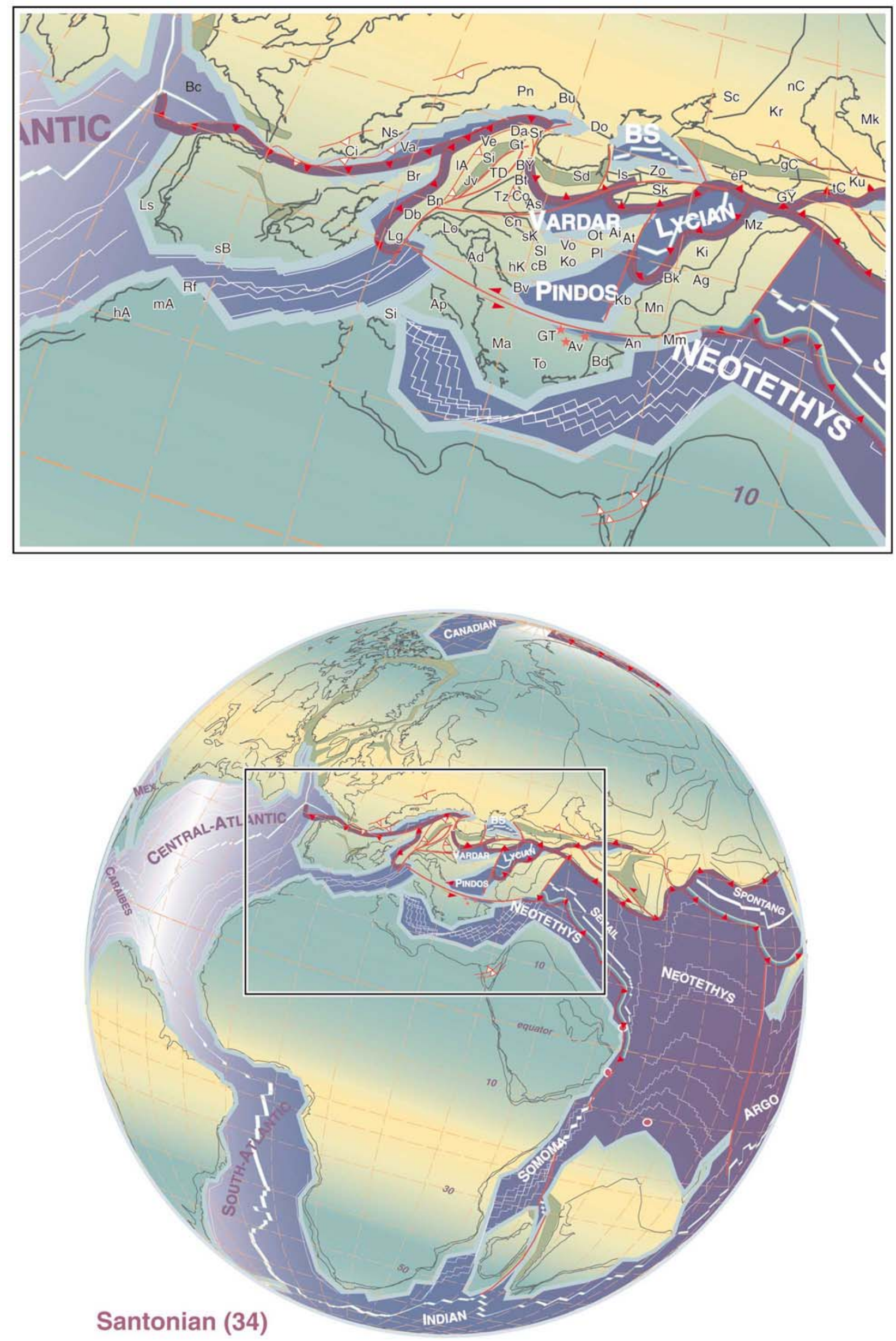

Figure 9. 


\section{Perm. Triassic Jurassic Cretaceous}

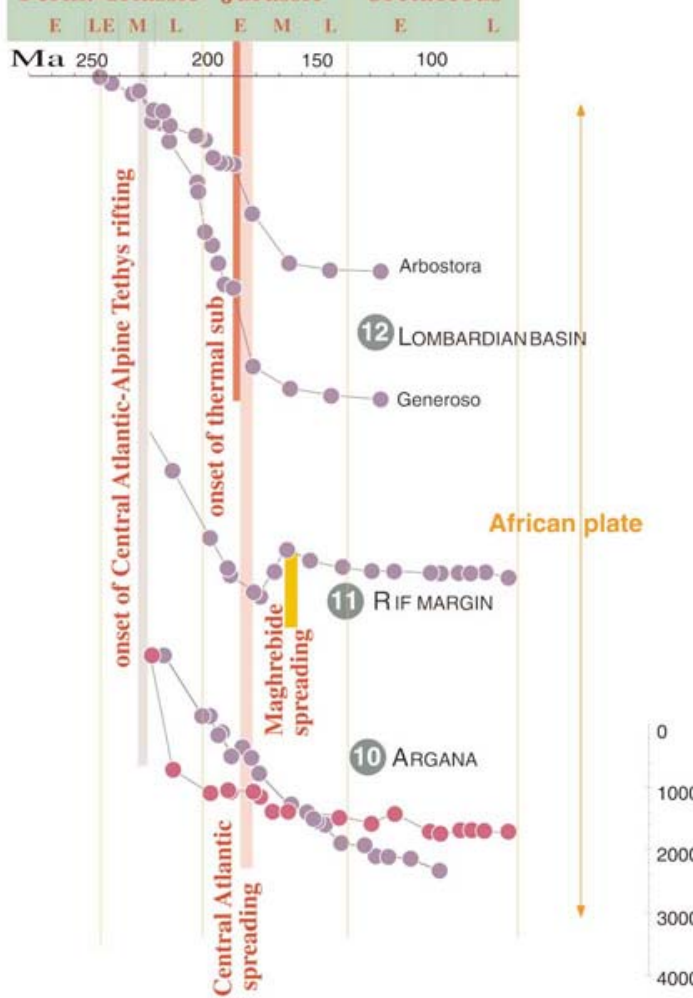

Tectonic subsidence with max bathymetric correction without eustatic correction

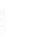

\section{Perm. Triassic Jurassic Cretaceous Tertiary/Q}

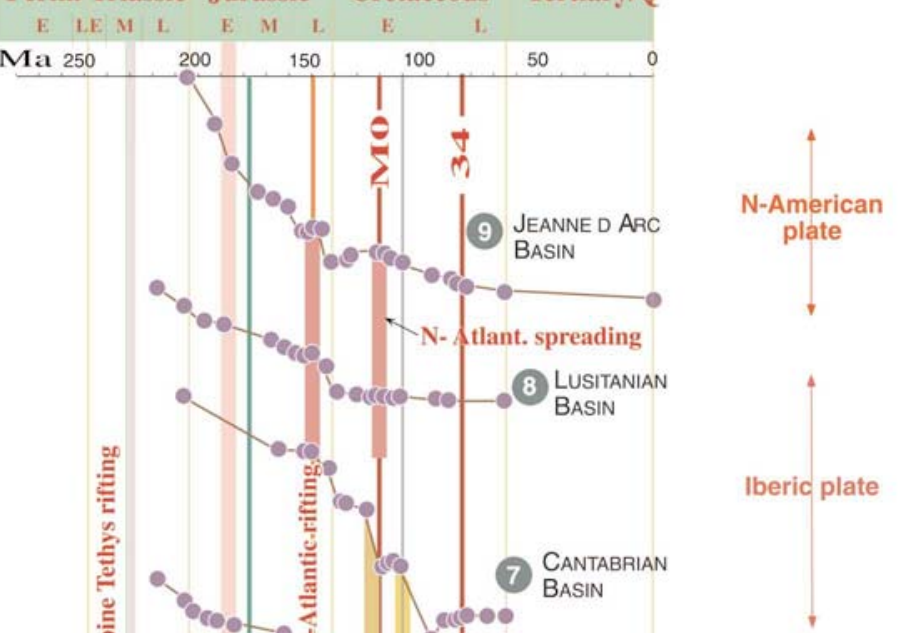

1000

2000

3000

$4000 \mathrm{~m}$

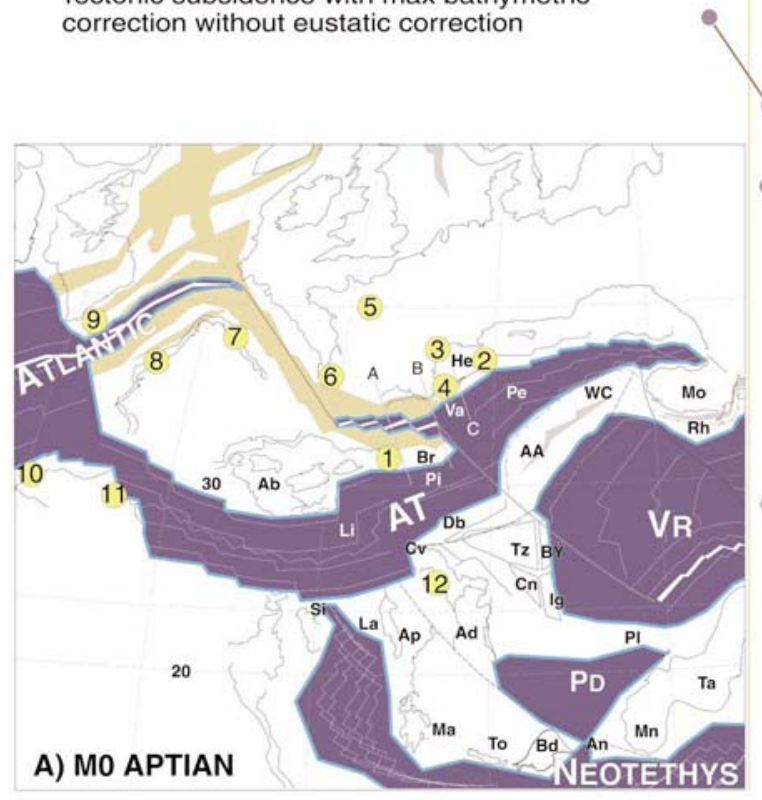

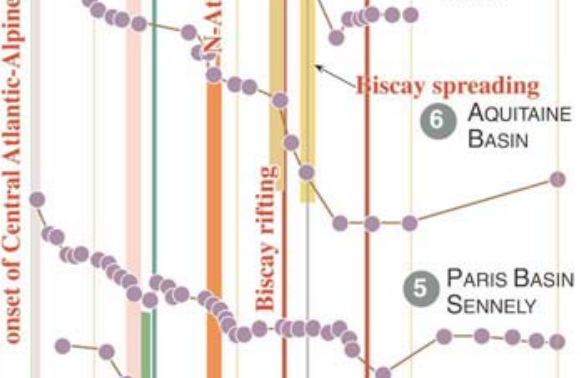

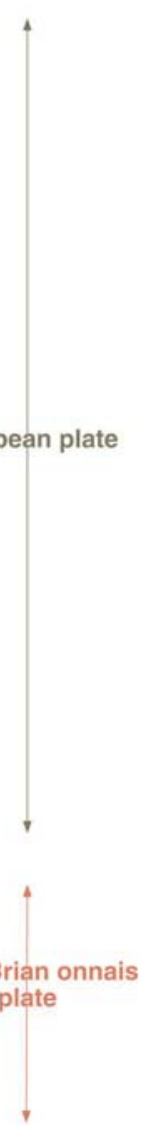

Figure 10. Synthetic subsidence curves for selected circum-Iberia and Atlantic domains (modified from Borel, 1997 and Stampfli and Borel, 2000) and location map. The subsidence program used to derived the curves is from R. Schegg., Time scale fromOdin (1994). 
accumulating thousands of meters of upper Cretaceous clastic deposits in a northward migrating fore-deep type basin (Debrand-Passard and Courbouleix, 1984). This shows a southward closure of the Pyrenean ocean on a Provençal transect, whereas a northward subduction took place on a Pyrenean transect (Vergés and Garcia-Senz, 2001), also recorded in Sardinia (Barca and Costamagna, 1997; Barca and Costamagna, 2000), but again a southward subduction took place westward in the Biscay ocean.

This Pyrenean orogen can be followed from the present Pyrenees eastward up to southern France (Provence), and continues in the Alps in the form of a large scale uplift of the Helvetic margin and local inversion of the Jurassic tilted blocks, well expressed by the deposits of the Niesen flysch (mainly Maastrichtian) and Meilleret flysch (Middle Eocene), sedimented on a structured Mesozoic basement. These flyschs clearly predate the Alpine collisional event in the Helvetic domain, characterised by the deposition of collisional flysch not before the earliest Oligocene.

Along the European margin it is interesting to note the similitude of facies between the Rheno-Danubian flysch and the Valais trough sequence (the Valais trilogy) from Albian to Late Cretaceous ((Stampfli, 1993 and references therein). The continuity of deep water clastic facies in these two domains allows to assign them to the same position with regard to the European margin (often referred as North Penninic basin; fig. 12). The presence of contourites and strong and changing current directions along the basin (Hesse, 1974) suggests a connection with major oceanic domains. In the Ligurian domain (south of the Briançonnais) such turbiditic deposits are absent, the Albo-Cenomanian formation being dominated by anoxic black-shale deposits. So the Valais trough, together with the Pyrenean ocean and the Bay of Biscay ocean, must be regarded as the connection between the Eastern Alpine Tethyan realm and the opening north Atlantic ocean during the Cretaceous and Paleogene.

\section{Exotic terrains and margin duplication}

\section{In the northern margin}

As discussed above, the separation of the Iberic plate from North-America in the Late Jurassic (the onset of spreading is dated as M0, Early Aptian - 121Ma; fig. 8) implies a separation of the Iberic plate from Europe too. This separation is brought about by the Pyrenean pullapart rift system. The Briançonnais domain was attached to Corsica/Sardinia and therefore to the Iberic plate (Stampfli ,1993). Thus, its former position was more to the SE than usually supposed, a proposal already made by Frisch (1979). The most internal south-Helvetic (Ultrahelvetic) domains, the lower Penninic SimploTicinese nappes and Valais zone (ie.Sion-Courmayeur zone, Sub-Médiane zone and the Bündnerschiefer area of central Switzerland) are therefore considered as former elements of the northern Piemont oceanic margin trapped by the eastward displacement of the Briançonnais terrain in front of them in Late Cretaceous times. This remnant trapped Jurassic oceanic strip with an Early Jurassic margin to the north and an Early Cretaceous margin to the south is called here the Valais trough, but was also sometimes referred as the north Penninic ocean or basin. This displacement induced a duplication of the Piemont northern margin in the present day Alpine orogen from the French Alps up to the Engadine window, but is not considered here to have any extension further eastward. The eastward escape of the Briançonnais was induced by the combined opening of the Atlantic and Bay of Biscay oceans and the large scale rotation of the Iberic plate together with Africa, as deduced from the magnetic anomalies from the Atlantic. This implies also a partial closure of the Valais trough already during the Late Cretaceous. The combined Africa-Iberia rotation was closely followed by a general shortening between AfricaIberia and Europe, culminating into the Pyrenean orogen. But it was only during the Alpine collision that the Briançonnais domain became an exotic terrain, obducted in the Alpine accretionary prism (fig.12).

The Alboran plate (Rif, internal Betic, Kabylies, Peloritan, Corso-Sardinia and Calabria microplates, (Wildi, 1983) formed the southern margin of the Iberic plate (fig. 3 to 9). This margin was affected by deformation processes as from Early Cretaceous (Puga et al., 1995); resedimentation of the Dorsale Calcaire (former rift shoulder) in the flysch basin starts in Cenomanian time, grading into major olistostromic deposits in Maastrichtian (Gübeli, 1982; Thurow, 1987). However, these deformation are most likely related to local inversion and strike slip displacement between Africa and Iberia rather than to subduction because no shortening can be demonstrated at that time between the two plates. Subduction under the Iberic plate started only in Eocene/Oligocene times as a result of the Pyrenean orogeny and graded into major terrain displacements during the late Tertiary opening of the Algero-Provençal ocean, liberating the Alboran blocks from their Iberic motherland (fig. 12). These displacements generated duplication of paleogeographic elements, creating pseudo oceanic sutures. We propose a displacement toward the SW of the Internal Betic domains (together with the Rif) subsequently incorporated into the Betic orogen as a terrain.

The Iberic margin is considered a Tertiary active margin developing back-arc spreading, and the African margin as a passive margin. Terrain displacement was related to the slab roll-back of the remnant Alpine Tethys Ligurian basin, (fig. 12) and the lateral detachment of its slab. The Apenninic accretionary prism developed on the eastern side of Iberia and by Late Miocene time the slab roll-back had reached the Ionian basin (the western most part of the NeoTethys ) and this led to the opening of the Tyrrhenian oceans as a new generation of back-arc, accompanied by the drifting of the Calabrian micro-plate to its present position (fig. 13).

\section{In the southern margin}

The Early Cretaceous rotation of Iberia-Africa, as well as the closing of the remnant Meliata domain induced the closure of the Liguro-Piemont part of the Alpine Tethys ocean. This closure is quite different on the Austrian transect and the Swiss transect due to the 


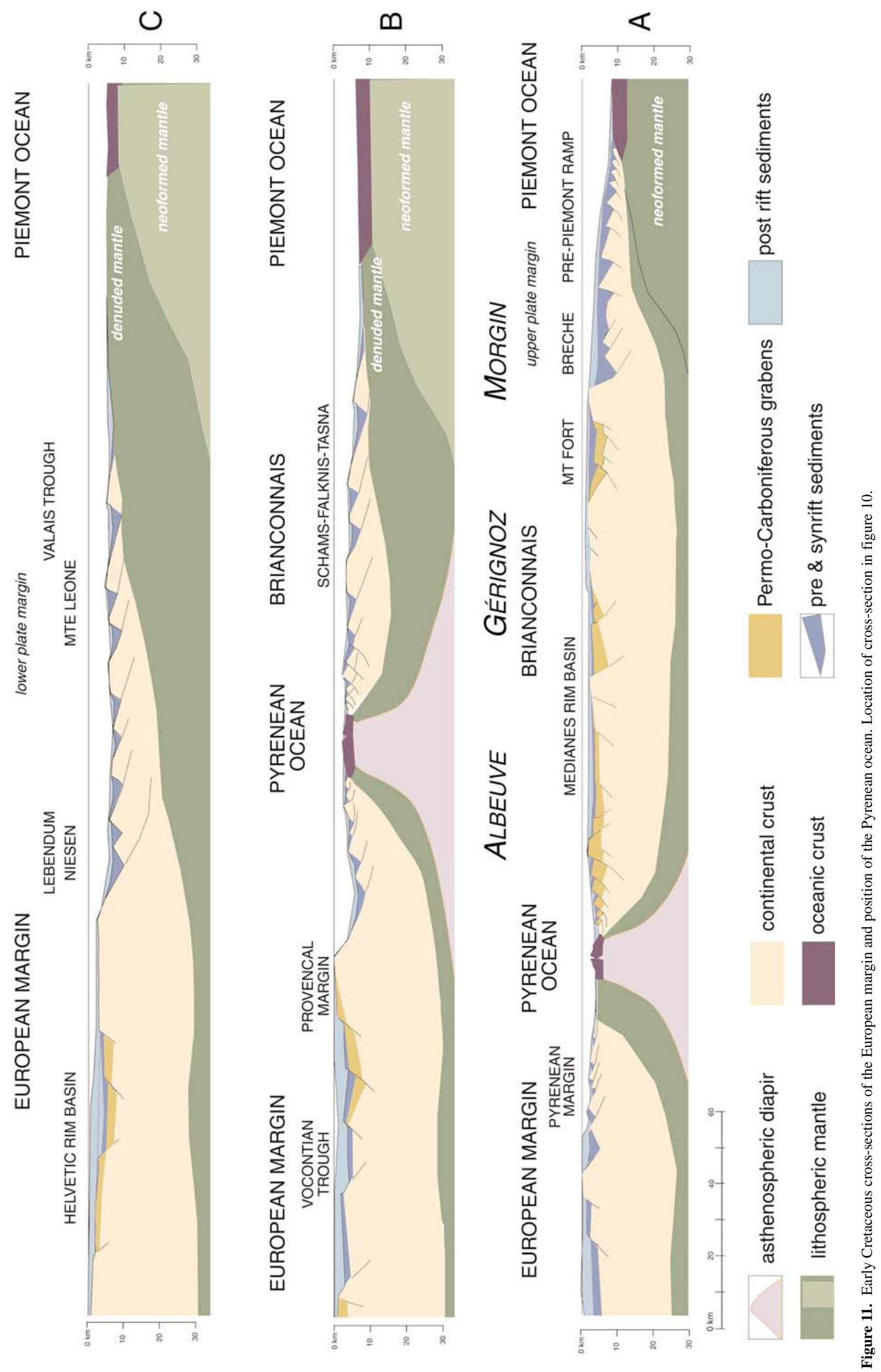




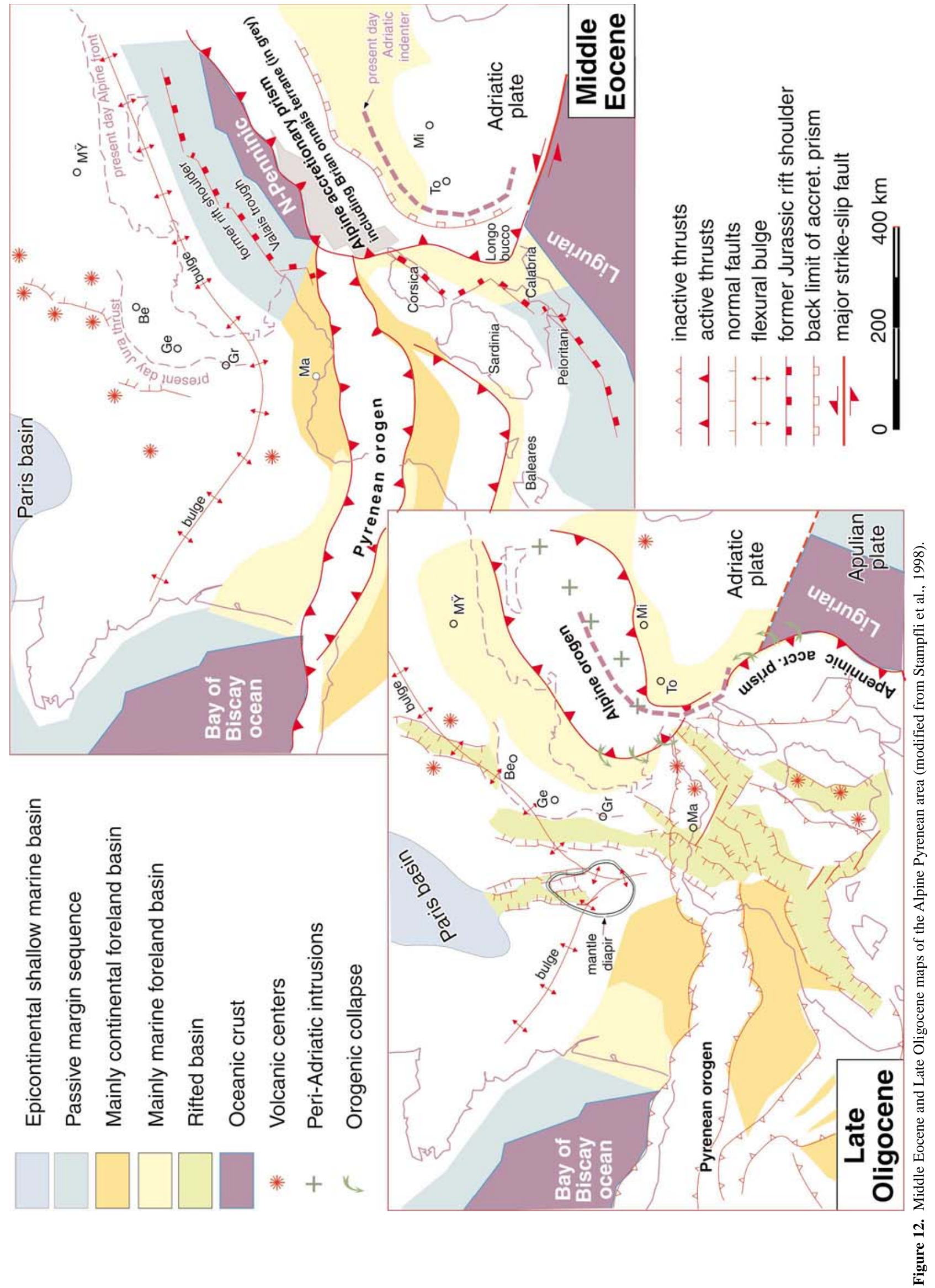


presence/absence of the Meliata-Vardar domain. In the eastern Alps transect the subduction of the Alpine Tethys is the consequence of the subduction of the Meliata domain since Jurassic time, the subduction there can be seen as a continuous process during which the AustroAlpine blocks were subducted and part of their covers was included in the accretionary prism to form the Middle and Upper Austro-Alpine nappe system (Faupl and Wagreich, 1999 and references therin). In the western Alps the Adria margin stayed passive for a longer time due to the fact that Iberia and Africa have the same wander path during the Cretaceous (at least between anomaly M0- Aptian and 34 - Santonian - fig. 7 to 9).

The subduction of the Piemont part of the Alpine Tethys is marked by HP/LT metamorphism of elements pertaining to the toe of the Austroalpine margin (Sesia massifs, Former back-stop of the prism) and to the accretionary prism s.str. (Tsaté nappe). Most of the eo-Alpine ages (Hunziker et al., 1992) seems now to be younger than formerly dated (e.g. Froitzheim et al., 1996), however some ages are still older than the onset of collision between the accretionary prism and the Briançonnais micro-continent and can for sure be related to subduction of the oceanic domain. Younger ages (Midle Eocene or younger) are related to the collision proper (Gebauer, 1999). Therefore the onset of oceanic subduction on a western Alps transect could be younger than proposed so far, but not younger than the incorporation of exotic elements in the accretionary prism represented by the Gets and Simme flysch. These exotic elements are made of ophiolitic blocks and blocks derived from the Lower Austro-Alpine margin, their minimum age is Cenomanian (Clément, 1986) and the onset of subduction of the Alpine Tethys can certainly be placed around that time (90-100 Ma). This time corresponds also to the onset of flysch deposition in the Lombardian rim basin (Bichsel and Häring, 1981). Before to become an active margin this western portion of the lower Austoalpine margin suffered a westward displacement in regards to Adria (Frank, 1987; Froitzheim et al., 1994; Trümpy, 1992) related to the closure of the Vardar/Hallstatt-Meliata oceanic realms and the important rotation of Africa at that time to which Adria was still attached. This induced trapping of Piemont oceanic crust or mantle between the Southern Alps domain (Adria) and the Lower Austroalpine units as found between the Canavese zone and the Sesia nappe (Venturini, 1995).

\section{Subduction and obduction processes}

Subduction and obduction processes affecting the oceanic sequences of the Piemont ocean are shown on figures 14 and 15. Spreading rates were obtained from the central Atlantic magnetic anomalies which allow to define the opening of the Alpine Tethys at least until Early Cretaceous. The rates of convergence between Africa and Europe are also derived from the Atlantic magnetic anomalies and reported along a transect perpendicular to the western Alps. We reported the evolution of the flexural bulge in time along this transect and defined its emplacement in regard of the Briançonnais domain and the Helvetic domain. In both areas the flexural bulge can be detected through a good preservation of the sedimentary sequences.

Theoretically, the flexural bulge related to the southward subduction of the Alpine Tethys affected the Briançonnais domain in Late Cretaceous already and could have been responsible for major hiatuses in the sedimentary record at that time and a very condensed section all together (Couches Rouges: Guillaume, 1986). Thereafter it affected the Helvetic margin (fig. 16) creating a general emersion of the Helvetic-Dauphinois and Subalpine domains since Paleocene time (Lihou, 1996, Allen et al., 1991, Burkhard and Sommaruga, 1998). However, Pyrenean inversion within the Helvetic margin and the eastward migration of the Briançonnais peninsula at that time, certainly strongly interfered with the flexural processes creating localised inversions of former tilted blocks (Niesen flysch: (Ackerman, 1986) and Meilleret flysch (Homewood, 1974) (fig. 16).

The time of incorporation of the different terrains is well established based on the age of associated flysch deposits (Caron et al., 1989). In the Piemont domain (fig. 14) on a western Alps transect, the Gurnigel flysch was deposited from Maastrichtian until middle Eocene (Caron et al., 1980a; Caron et al., 1980b) and followed by the chaotic complex of likely late Middle Eocene age (Dall'Agnolo, 2000; Steffen et al., 1993), which includes elements from the Briançonnais margin (Couches Rouges, Breccia nappe). On the Briançonnais domain the deposition of the Médianes flysch lasted until Lutetian time (NP 15, 47 to 43 Ma: Guillaume, 1986) it is a rather distal flysch deposit, precluding any deposition on an already detached substratum. Thus the subduction of the Briançonnais domain did not take place before the late Middle Eocene (fig. 17), this is confirmed by metamorphic ages from the Briançonnais basement starting around $38 \mathrm{Ma}$ (Markley et al., 1995)

Slivers of basement with part of their cover were detached from the subducting slab and underplated; they form presently the bulk of the middle Penninic domain (Escher et al., 1997). Part of the cover was detached from the basement and incorporated in the still active accretionary prism to form the future Préalpes Médiannes (Mosar et al.,1996). The exotic Briançonnais sliver was overthrusted on the Valais trough and a Late Eocene mélange is found at its base in the Valais (Pierre Avoi uni, Bagnoud et al. 1998).Along the same suture MORB are found in a few places in the Valais and in eastern Switzerland (in the Bündnerschiefer) (Dürr et al., 1993). They have a signature not different from other Piémont MORB, and as said above are derived from a piece of the Alpine Tethys trapped between the Helvetic and the exotic Briançonnais terrain. The matrix of mélanges found directly under the Briançonnais are only dated in the Pierre Avoi unit in Valais, one cannot exclude that older mélanges (Late Cretaceous) are present, mainly in the Bündnerschiefer domain and related to the Cretaceous translation of the Briançonnais terrain.

Elements from the Valais trough and the distal Helvetic margin were then accreted and are represented by the 


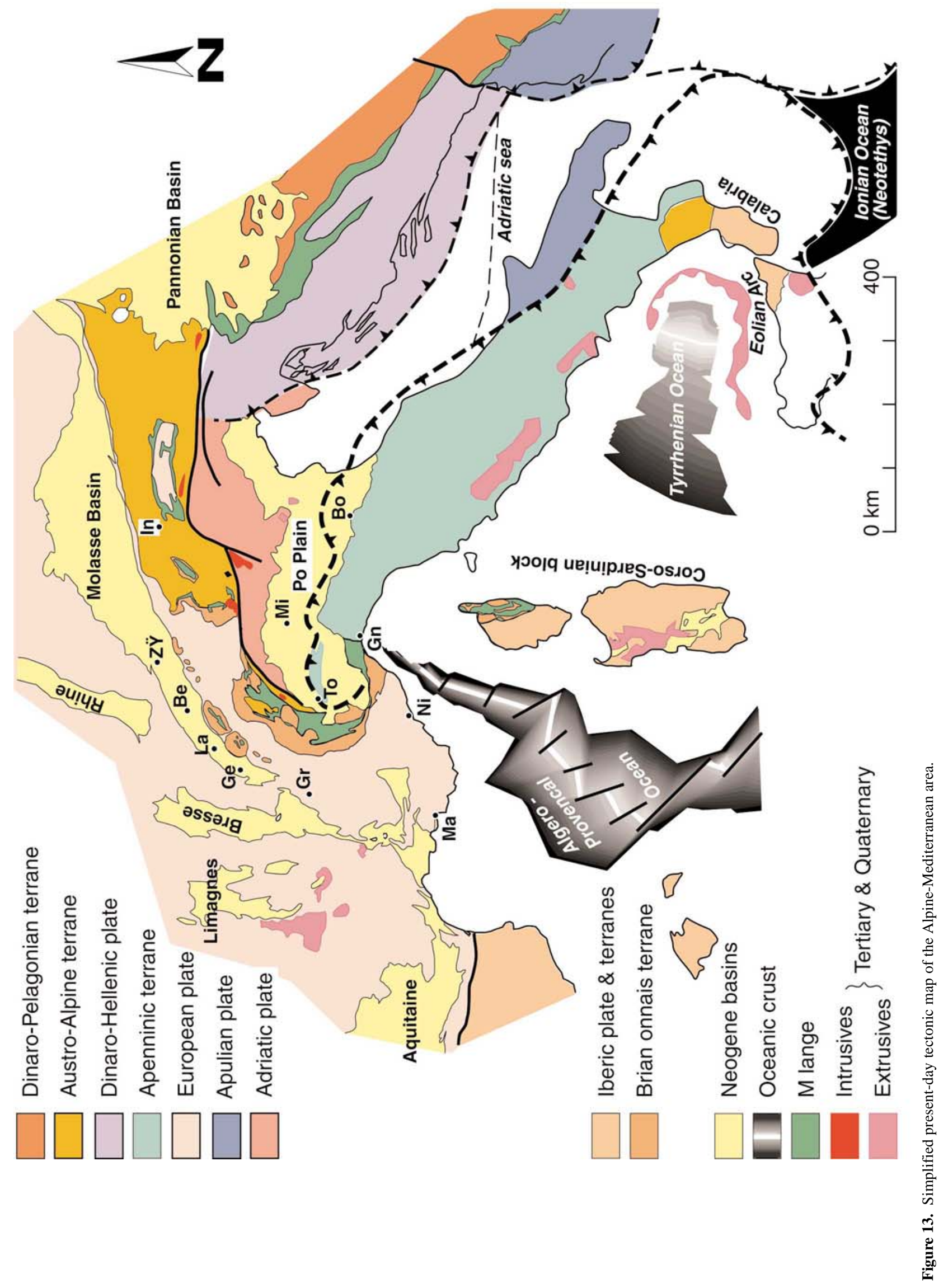




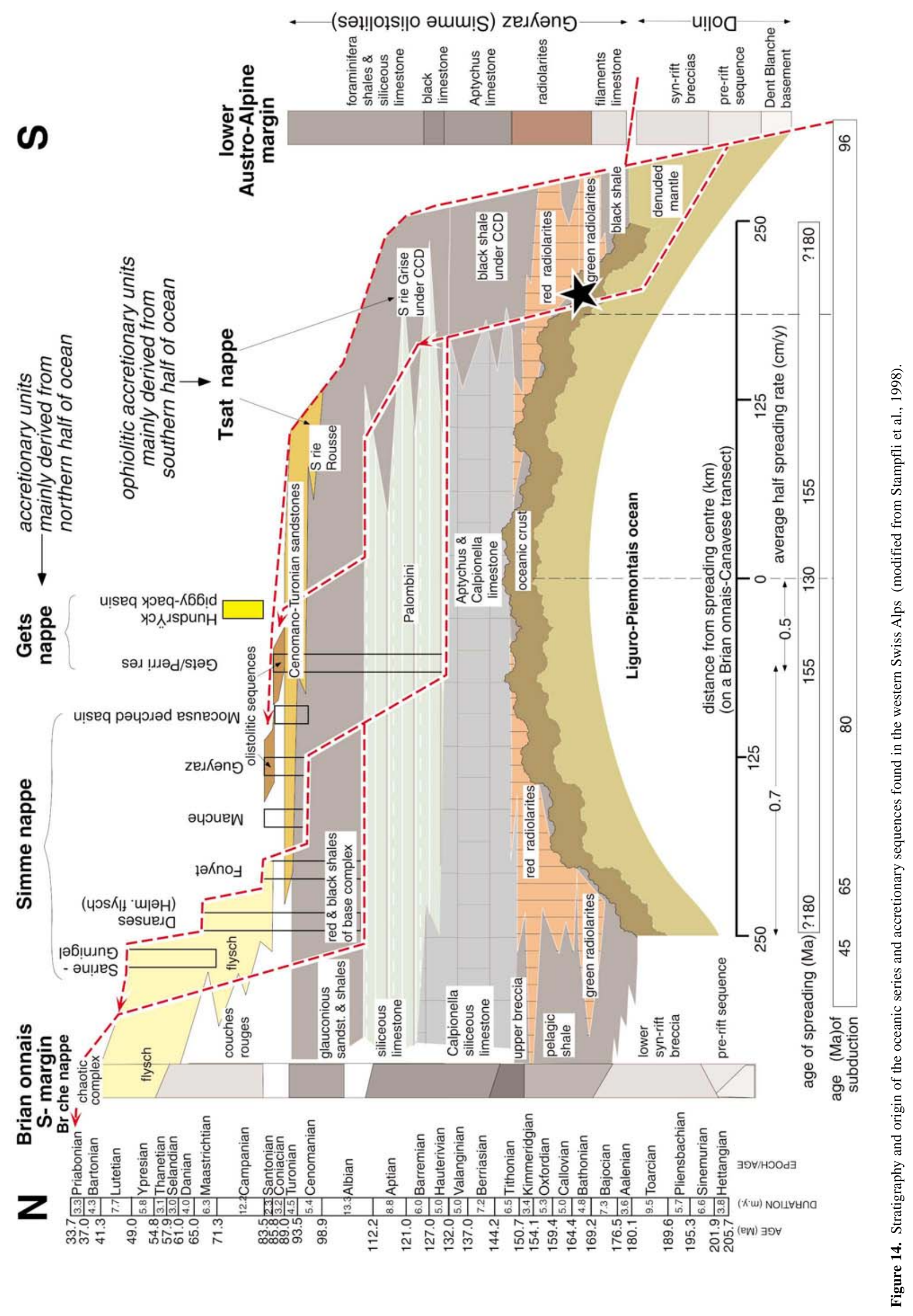




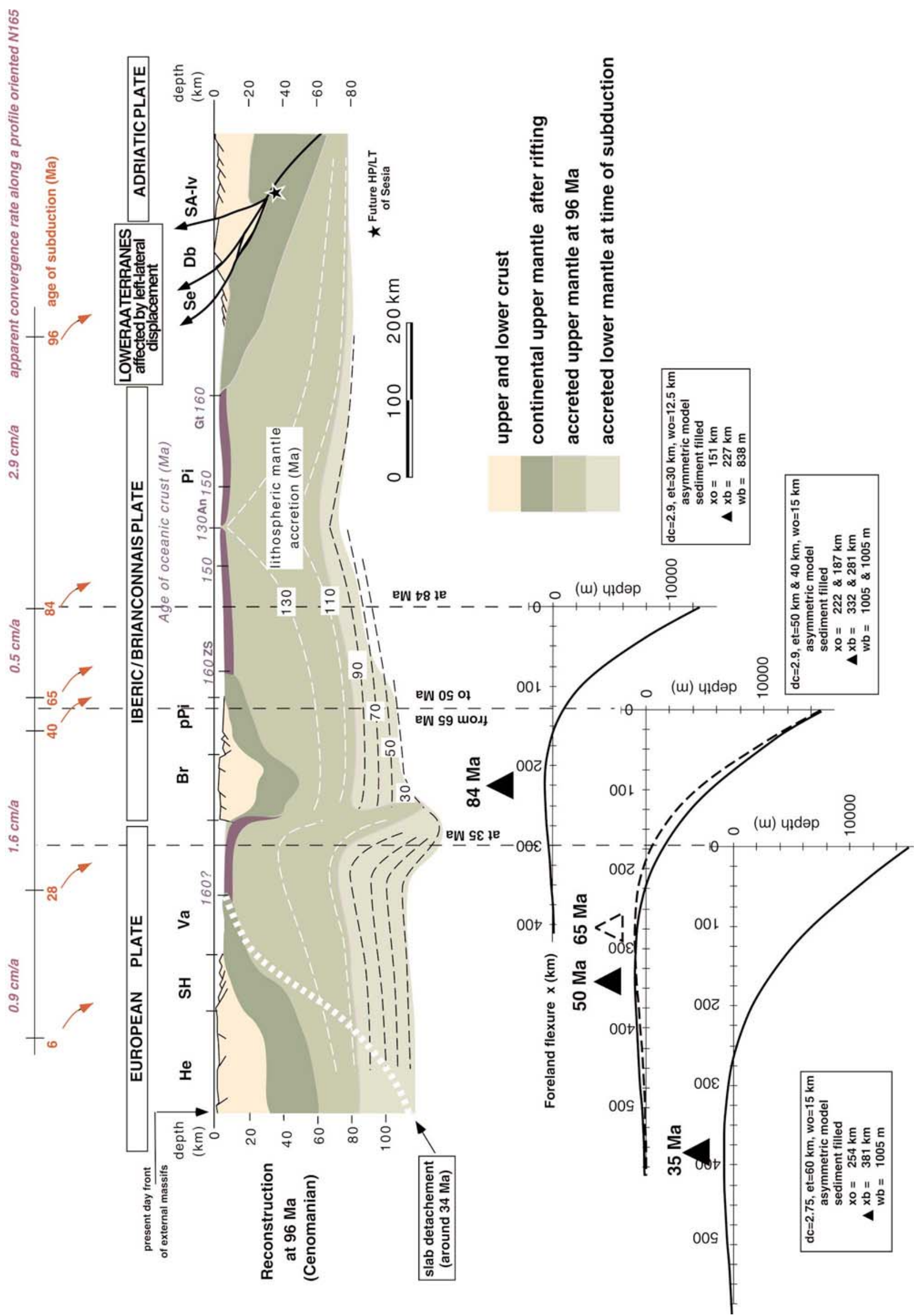

Figure 15. Evolution of the flexural bulge during the closing of the Alpine Tethys (modified from Stampfli et al., 1998). The flexural programme used to construct the curves is from M. Burkhard (Neuchâtel). 
"Valaisan trilogy" (Aroley, Marmontains, Saint Christophe: Burri, 1958) made of poorly dated deep-sea sediments, outcroping nowadays in the Sion-Courmayeur zone.

Incorporation in the prism of elements pertaining to the Helvetic margin (fig. 12) is well constrained by the ages of the south Helvetic flysch (e.g. Jeanbourquin, 1994; Jeanbourquin and Burri, 1991) and Sardona flysch (in east Switzerland)(Lihou, 1996). It can be placed during or just after the Priabonian since the Ultrahelvetic flysch has been dated as Late Eocene (37 to 33.7 Ma, e.g. Charollais et al., 1993; Kindler, 1988). Most of the attenuated crust from the Helvetic margin was subducted (Burkhard and Sommaruga, 1998).

General metamorphism of the south Helvetic domain spreads from 30 to $20 \mathrm{Ma}$ (cooling ages)(Steck and Hunziker, 1994) and mylonites from the Helvetic nappes have been dated between 32 and 13 Ma (Kirshner et al., 1996).

Further subduction of the thicker part of the margin led to the decoupling of major parts of the crystalline basement represented by the Mont Blanc and Aiguilles Rouges massifs. This decoupling was made possible by the increased heat flux following the Alpine Tethys slab detachment or delamination around 35-33 Ma (Wortel and Spakman, 1992; Stampfli and Marchant, 1995). This delamination corresponds to the emplacement of the periAdriatic intrusives (e.g. Bergell intrusion) and the rapid Early Oligocene transgression on the Helvetic domain following temporary de-flexuring of the lower plate. This phenomenon allowed further subduction of 50 to $150 \mathrm{~km}$ of European plate (Marchant and Stampfli, 1997b).

\section{Vergence of subduction}

As we have seen above, the southward subduction of the Alpine Tethys ocean is related to the history of the Meliata-Maliac and Vardar domain. The change of vergence of the Alpine Tethys subduction westward is directly linked to the connection between the Alps and the Apennines (fig. 12). It must be emphasized here that the Penninic prism is older (Late Cretaceous-Eocene) than the Apenninic one (Oligocene- Pliocene), actually one started when the other one stopped. If there is confusion between the two it is because the Apenninic prism is re-mobilising parts of the Penninic prism as exotic elements (e.g. the Braco ophiolitic ridge; Elter et al., 1966; Hoogenduijn Strating, 1991). These complex situations of duplication of paleogeographic elements led to many palaeogeographic interpretations (most of them done only on $2 \mathrm{D}$ cross-sections) not taking into account large-scale lateral displacement of terrains and diachronous subduction events. Most models propose several parallel small oceans, separating even smaller strips of continental crust. These solutions are not feasible, mainly in regard to rheological constraints on plate boundaries and sedimentological evolution of these margins.

In this framework where large scale constraints are taken into account, ophiolites of the Apenninic prism are regarded as mainly derived from the former Alpine prism which collided with the Iberic plate in Corsica and Calabria in Eocene times (fig. 12). These oceanic elements were re-mobilised when the remnant Alpine Tethys oceanic domain (Ligurian basin) south of the Iberic plate started to subduct northward.

\section{Conclusions}

We wanted to emphasize here the necessity to incorporate detailed field studies in large scale reconstructions in order to better constrain them. On the other hand, large scale reconstructions provide a unified and simple continental margins framework in which local information can be organized. In doing so, it can be shown in the Alps, that the very complex structural pattern does not correspond to a complex palaeogeography. If complexity there is, it is due to an interaction between different plates, which somehow have a common junction in the Alpine area. These European, African, Iberic, Alboran and Adriatic plates can be easily recognised through their sedimentary series and subsidence behaviour, and their interaction during collision processes through foreland basin evolution.

We sum up here the major characteristics of the western Tethyan area:

First of all, the evolution of the eastern part of the orogen (Austria-Carpathes) has little to do with its western counter part (western Alps), they only go through a common fate only since the Late Cretaceous through a final and unified southward subduction of the Alpine Tethys and the Oligo-Miocene collision with Europe. Before that, the eastern Alps and Carpathian area are related to the closure of the Meliata-Vardar domain.

Similarly, the western Alps and Apenninic area have little in common, they locally share bits and pieces of the Alpine Tethys ophiolitic sequences, but the comparison stops at that. The Apenninic accretionary prism is issued from a northward subduction of a remnant Alpine Tethys sea-floor under Spain since Oligocene times. In Late Miocene, the slab roll-back eventually reached another oceanic remnant in the Ionian sea region consisting of the western most part of the NeoTethys ocean.

The fate of the Pyrenean domain is clearly related to a common wandering of Africa and Iberia between M0 and the Middle Eocene. This too often forgotten fact implies that the former northern margin of the Alpine Tethys had to be cut by the Pyrenean rift system, and a direct connection established between the two oceanic systems Pyrenees-Biscay and Alpine Tethys. In order to avoid major Late Cretaceous collision or opening between Europe and Iberia, the plate limit had to be located along a grand circle, therefore the Iberian northern plate limit can be established with some confidence, as well as the former position of the Briançonnais domain. The ensuing duplication of the European margin can clearly be derived from thorough field investigation in the western Alps.

We hope to have provided here basic hard fact type information, which, somehow, should not be ignored by anybody who would be plate mover. But this is certainly not the end of the story, the Adria-Apulia separation/union being still far from a widely accepted solution, and we welcome any new information on the subject. 


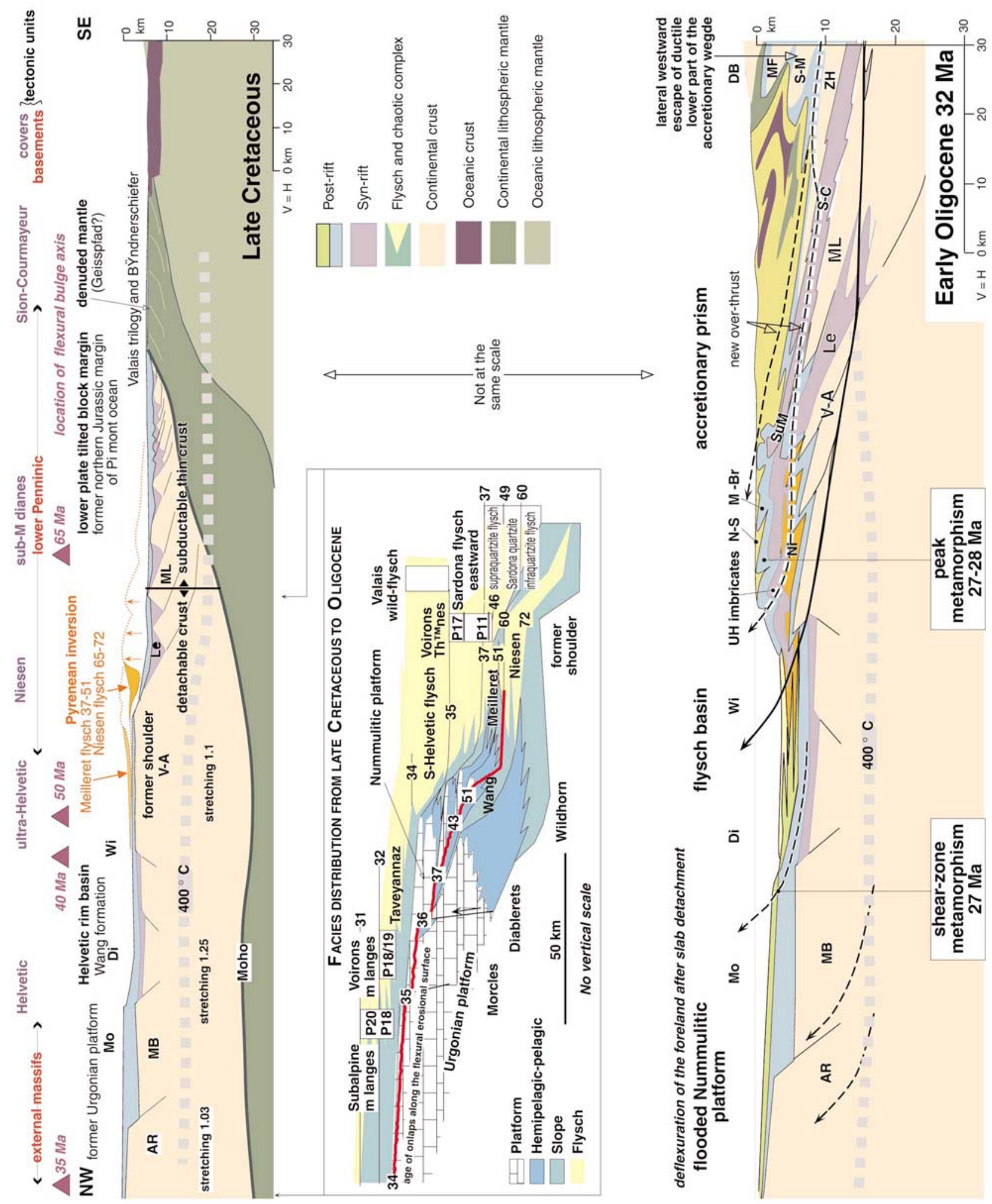

Figure 16. Reconstruction of the Helvetic margin in Maastrichtian and Early Oligocene (modified from Stampfli et al., 1998). See text for discussion and references about the timing of events. Stretching factor from Loup (1992). AR, Aiguilles rouges massif; Di, Diablerets nappe domain; DB, Dent Blanche nappe; Le, Lebendun sequence; MB, Mont Blanc massif; MF, Mont Fort nappe; Mo, Morcles nappes domain; Mé-Br, Médianes and Brèches nappes; ML, Monte Leone nappe; Ni, Niesen nappe; N-S, nappes Supérieures; S-C, zone Sion-Courmayeur; S-M, Siviez-Mischabel nappe; SuM, zone sub-Médianes; Ts, Tsaté nappe; V-A, Verampio-Antigorio napes; Wi, Wildhorn nappe domain; ZH-Po, zone Houillère, Pontis nappes. 

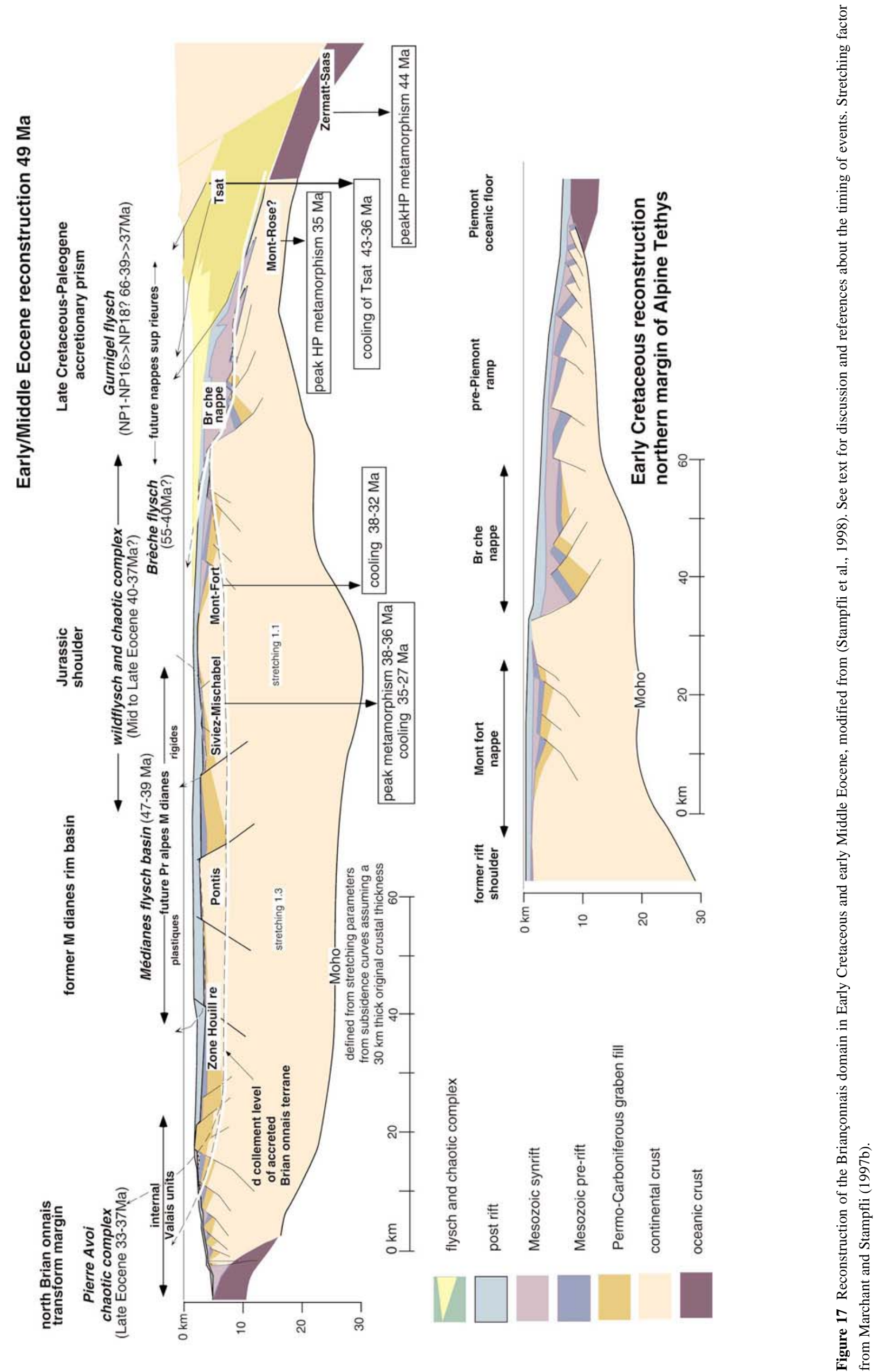


\section{Acknowledgements}

We thank all the scientists involved in the IGCP 369 project, and all our colleagues of the University of Lausanne who contributed with their knowledge of the Alpine region. Research supported by FNRS grant no: 2053'646.98 and 20-61'885.00.

\section{References}

Ackermann, A. 1986. Le flysch de la nappe du Niesen. Eclogae geologicae Helvetiae. 79(3), 641-684.

Allen, P.A., Crampton, S.L. and Sinclair, H.D. 1991. The inception and early evolution of the North Alpine Foreland Basin, Switzerland. Basin Research. 3, 143-163.

Bagnoud, A., Wernli, R. and Sartori, M. 1998. Découverte de foraminifères planctoniques dans la zone de SionCourmayeur à Sion. Eclogae geologicae Helvetiae. 91(3), 421-429.

Barca, S. and Costamagna, L.C. 1997. Compressive "Alpine" tectonics in Western Sardinia (Italy): geodynamic consequences. Comptes Rendus Académie des Sciences. 325, 791797.

Barca, S. and Costamagna, L.C. 2000. Il Bacino paleogenico del Sulcis-Iglesiente (Sardegna SW): nuovi dati stratigraphicostrutturali per un modello geodinamico nell'ambito dell'orogenesi pirenaica. Bollettino della Società geologica Italiana. 119, 497-515.

Baumgartner, P.O. 1985. Jurassic sedimentary evolution and nappe emplacement in the Argolis Peninsula (Peloponesus, Greece) 99. Mémoires de la Société Helvétique des Sciences Naturelles, Birkhäuser, Basel. 111 p.

Berthelsen, A. 1992b. Tectonic evolution of Europe - from Precambrian to Variscan Europe. In: D. Blundell, R. Freeman and S. Mueller (Eds.), A continent revealed - the European Geotraverse. University Press Cambridge, 153-163.

Bertotti, G., Picotti, V., Bernoulli, D. and Castellarin, A. 1993. From rifting to drifting: tectonic evolution of the SouthAlpine upper-crust from the Triassic to the Early Cretaceous. Sedimentary Geology. 86, 53-76.

Bichsel, M. and Häring, M.O. 1981. Facies evolution of late Cretaceous flysch in Lombardy (Northern Italy). Eclogae geologicae Helvetiae. 74(2), 383-420.

Bill, M., Bussy, F., Cosca, M., Masson, H. and Hunziker, J.C. 1997. High precision $\mathrm{U}-\mathrm{Pb}$ and 40Ar/39Ar dating of an Alpine ophiolite (Gets nappe, French Alps). Eclogae geologicae Helvetiae. 90, 43-54.

Borel, G. 1995. Préalpes médianes romandes: courbes de subsidence et implications géodynamiques. Bulletin de la Société vaudoise des Sciences naturelles. 83(4), 293-315.

Borel, G. 1997. Dynamique de l'extension mésozoique du domaine briançonnais: les Préalpes médianes au Lias. Phd Thesis, Lausanne

Burkhard, M. and Sommaruga, A. 1998. Evolution of the Swiss Molasse basin: structural relations with the Alps and the Jura belt. In: A. Mascle, A. Puiddefabregas, H.P. Luterbacher and M. Fernandez (Eds.), Cenozoic Basins of western Europe. Special Publications of the Geological Society of London 134, 279-298.

Burri, M. 1958. La zone de Sion-Courmayeur au nord du Rhône.
Matériaux pour la Carte géologique de la Suisse, Nouvelle Série. $105,45 \mathrm{p}$.

Caron, C., Homewood, P., Morel, R. and van Stuijvenberg, J. 1980a. Témoins de la Nappe du Gurnigel sur les Préalpes Médianes: une confirmation de son origine ultrabriançonnaise. Bull. Soc. Frib. Sc. Nat. 69(1), 64-79.

Caron, C., Homewood, P. and van Stuijvenberg, J. 1980b. Flysch and Molasse of Western and Central Switzerland. In: R. Trümpy (Ed.), Geology of Switzerland, a guide-book, Part B, Geological Excursions. Wepf. and Co. Basel, 274-278.

Caron, C., Homewood, P. and Wildi, W. 1989. The original Swiss Flysch: A reappraisal of the type deposits in the Swiss Prealps. Earth-Science Reviews. 26, 1-45.

Charollais, J. et al. 1993. Précisions stratigraphiques sur les Collines du Faucigny, Préalpes ultrahevétique de haute Savoie (France). Eclogae geologicae Helvetiae. 86(2), $397-$ 414.

Channell, J.E.T. 1992. Paleomagnetic data from Umbria (Italy): implications for the rotation of Adria and Mesozoic apparent polar wander paths. Tectonophysics. 216, 365-378.

Channell, J.E.T. 1996. Paleomagnetism and Paleogeography of Adria. In: A. Morris and D.H. Tarling (Eds.), Paleomagnetism and tectonics of the Mediterranean region. Geological Society Special Publication 105, 119132.Dall'Agnolo, S. 2000. Le Crétacé supérieur de la Nappe de la Brèche (Préalpes franco-suisses). Données nouvelles et essai de synthèse stratigraphique et poaléogéographique. Eclogae geologicae Helvetiae. 93(2), 157-174.

Clément, J.P. 1986. Les sédiments pélagiques de la nappe de la Simme (Préalpes romandes), Fribourg, 906.

De Bono, A. 1998. Pelagonian margins in Central Evia Island (Greece). Stratigraphy and geodynamic evolution. on line (Lausanne) Thesis, Lausanne, Thèse.

de Jonge, M.R., Wortel, M.J.R. and Spakman, W. 1994. Regional scale tectonic evolution and the seismic velocity structure of the lithosphere and upper mantle: the Mediterranean region. J. Geophys. Res. 99(B6), 12091-12108.

Debrand-Passard, S. and Courbouleix, S. 1984. Synthèse géologique du S-E de la France. Mémoires du Bureau de Recherches Géologiques et Minières Orléans. 126.

Dürr, S.B., Ring, U. and Frisch, W. 1993. Geochemistry and geodynamic significance of North Penninic ophiolites from the central Alps. Schweizerische Mineralogische und Petrographische Mitteilungen. 73, 407-419.

Elter, G., P., E., Sturani, C. and Weidmann, M. 1966. Sur la prolongation du domaine ligure de l'Apennin dans le Montferrat et les Alpes et sur l'origine de la nappe de la Simme s.l. des Préalpes romandes et chablaisiennes. Archives des Sciences, Genève. 19(3), 279-377.

Escher, A., Hunziker, J., Masson, H., Sartori, M. and Steck, A. 1997. Geologic framework and structural evolution of the western Swiss-Italian Alps. In: O.A. Pfiffner, P. Lehner, P.Z. Heitzman, S. Mueller and A. Steck (Eds.), Deep structure of the Swiss Alps - Results from NRP 20. Birkhäuser AG. Basel, 205-222.

Escher, A., Masson, H. and Steck, A. 1988. Coupes géologiques des Alpes occidentales suisses. Mémoires de Géologie (Lausanne). 2, $11 \mathrm{p}$.

Faupl, P. and Wagreich, M. 1999. Late Jurasic to Eocene Palaeogeography and geodynamic evolution of the Eastern 
Alps. Mitteilungen der Österreichischen Geologischen Gesellschaft. 92, 79-94.

Favre, P. and Stampfli, G.M. 1992. From rifting to passive margin : the example of the Red Sea, Central Atlantic and Alpine Tethys. Tectonophysics. 215, 69-97.

Frank, W. 1987. Evolution of the Austroalpine elements in the Cretaceous. In: H. Flügel and P. Faupl (Eds.), Geodynamics of the eastern Alps. Frank Deuticke Vienna, 379-406.

Frisch, W. 1979. Tectonic progradation and plate tectonic evolution of the Alps. Tectonophysics. 60, 121-139.

Froitzheim, N. 2001. Origin of the Monte Rosa nappe in the pennine Alps - a new working hypothesis). Geol. Soc. America Bull. 113(5), 604-614.

Froitzheim, N. and Manatschal, G. 1996. Kinematics of Jurassic rifting, mantle exhumation, and passive-margin formation in the Austroalpine and Penninic nappes (Eastern Switzerland). Geological Society of America Bulletin. 108(9), 1120-1133.

Froitzheim, N., Schmid, S. and Conti, P. 1994. Repeated change from crustal shortening to orogen-parallel extension in the Autroalpine units of Graubüunden. Eclogae geologicae Helvetiae. 87(2), 559-612.

Froitzheim, N., Schmid, S. and Frey, M. 1996. Mesozoic paleogeography and the timing of eclogite-facies metamorphism in the Alps: a working hypothesis. Eclogae geologicae Helvetiae. 89(1), 81-110.

Gebauer, D. 1999. Alpine geochronology of the western Alps: new constraintsfor a complex geodynamic evolution. Schweizerische Mineralogische und Petrographische Mitteilungen. 79, 191-202.

Gübeli, A.A. 1982. Stratigraphische und sedimentologische Untersuchung der detritischen Unterkreide-Serien des zentralen Rif (Marokko). Ph.D. Thesis Thesis, Zürich.

Guillaume, M. 1986. Revision stratigraphique des Couches Rouges de la nappe des Préalpes médianes romandes. PhD thesis Thesis, Fribourg.

Haas, J., Kovacs, S., Krystyn, L. and Lein, R. 1995. Significance of Late Permian-Triassic facies zones in terrane reconstructions in the Alpine-North Pannonian domain. Tectonophysics. 242, 19-40.

Hesse, R. 1974. Long-distance continuity of turbidites: possible evidence for an early Cretaceous trench abyssal plain in the East Alps. Geological Society of America Bulletin. 85, 859870.

Homewood, P. 1974. Le flysch du Meilleret (Préalpes romandes) et ses relations avec les unités l'encadrant. Eclogae geologicae Helvetiae. 67(2), 349-401.

Hoogenduijn Strating, E.H. 1991. The evolution of the Piemonte-Ligurian ocean, a structural study of ophiolite complexes in Liguria (NW Italy). Geologica ultraiectina. 74, $127 \mathrm{p}$.

Hunziker, J.C., Desmons, J. and Hurford, A.J. 1992. Thirty-two years of geochronological work in the Central and Western Alps: a review on seven maps. Mémoires de Géologie (Lausanne). 13, $59 \mathrm{p}$.

Jeanbourquin, P. 1994. Early deformation of Ultrahelvetic mélanges in the Helvetic nappes (Western Swiss Alps). J. Struct. Geol. 16(10), 1367-1383.

Jeanbourquin, P. and Burri, M. 1991. Les métasédiments du Pennique inférieur dans la région de Brigue-Simplon. Lithostratigraphie, structure et contexte géodynamique dans le bassin valaisan. Eclogae geologicae Helvetiae. 84(2), 463481.

Kilian, W. 1891. Note sur l'histoire et la structure géologique des chaînes alpines de la Maurienne, du Briançonnais et des régions adjacentes. Bulletin de la Société géologique de France. 3(XIX), 571-661.

Kindler, P. 1988. Géologie des wildflyschs entre Arve et Giffre (Haute-Savoie, France). Thèse $n^{\circ} 6$ Thesis, Univ. Genève.

Kirschner, D.L., Cosca, M.A., Masson, H. and Hunziker, J.C. 1996. Staircase 40Ar/39Ar spectra of fine-grained white mica: Timing and duration of deformation and empirical constraints on argon diffusion. Geology. 24(8), 747 - 750.

Kozur, H. 1991. The evolution of the Meliata-Hallstatt ocean and its significance for the early evolution of the Eastern Alps and western Carpathians. In: J.E.T. Channell, E.L. Winterer and L.F. Jansa (Eds.), Paleogeography and paleoceanography of Tethys. Palaeogeogr. Palaeoclimatol. Palaeoecol. Elsevier 87, 109-135.

Lempicka-Münch, A. 1996. La géologie de la zone des cols de l'Oberland Bernois entre Geils (Adelboden) et la Sarine, Université de lausanne, Lausanne.

Lihou, J.C. 1996. Stratigraphy and sedimentology of the Sardona unit, Glarus Alps: Upper Crteaceous/middle Eocene deep marine flysch sediments from the Ultrahelvetic realm. Eclogae geologicae Helvetiae. 89(2), 721-752.

Loup, B. 1992. Mesozoic subsidence and stretching models of the lithosphere in Switzerland (Jura, Swiss Plateau and Helvetic realm). Eclogae geologicae Helvetiae. 85(3), 541572.

Luzieux, L. and Ferrari, O.M. 2002. Etude géologique et minéralogique du secteur du Col du Galibier (Savoie, France): implications géodynamiques. Msc Thesis, Lausanne Univ.

Malod, J.A. and Mauffret, A. 1990. Iberian plate motion during the Mesozoic. Tectonophysics. 184, 261-278.

Manatschal, G. 1995. Jurassic rifting and formation of a passive continental margin (Platta and Err nappes, Eastern Switzerland): geometry, kinematics and geochemistry of fault rocks and comparison with the Galicia margin, Diss. ETH Nr. 11188, Zürich

Manatschal, G. and Bernoulli, D. 1998. Rifting and early evolution of ancient ocean basins; the record of the Mesozoic Tethys and the Galicia-Newfoundland margins. In: J. Erzinger, C. Sibuet Jean and M. Talwani (Eds.), Volcanic margins. Marine Geophysical Researches. Kluwer Academic Publishers Dordrecht, Netherlands 20; 4, 371-381.

Marchant, R. 1993. The Underground of the Western Alps. Mémoires de Géologie (Lausanne). 15, 137 p.

Marchant, R.H. and Stampfli, G.M. 1997a. Crustal and lithospheric structures of the Western Alps: geodynamic significance. In: O.A. Pfiffner, P. Lehner, P.Z. Heitzman, S. Mueller and A. Steck (Eds.), Deep structure of the Swiss Alps Results from NRP 20. Birkhaüser AG. Basel, 326-337.

Marchant, R.H. and Stampfli, G.M. 1997b. Subduction of continental crust in the Western Alps. Tectonophysics. 269(3-4), 217-235.

Markley, M., Teyssier, C. and Cosca, M. 1995. Deformation vs cooling ages:the application of the 40Ar/39Ar method to synkynematic white micas, G. S. A. Annual meeting, NewOrleans. 
Masson, H. 1976. Un siècle de géologie des Préalpes: de la découverte des nappes à la recherche de leur dynamique. Eclogae geologicae Helvetiae. 69(2), 527-575.

Masson, H., Herb, R. and Steck, A. 1980. Helvetic Alps of Western Switzerland. In: R. Trümpy (Ed.), Geology of Switzerland, part B. Wepf \& Co. Basel, 109-135.

Montigny, R., Azambre, B., Rossy, M. and Thuizat, R. 1986. KAr study of Cretaceous magmatism and metamorphism in the Pyrenees: age and length of rotation of the Iberian peninsula. Tectonophysics. 129, 257-273.

Moreau, M.G., Canérot, J. and Malod, J.-A. 1992. Paleomagnetic study of Mesozoic sediments from the Iberian Chain (Spain) suggestions for Barremian remagnetization and implications for the rotation of Iberia. Bull. Soc. géol. France. 163(4), 393-402.

Mosar, J., Stampfli, G.M. and Girod, F. 1996. Western Préalpes médianes: timing and structure. A review. Eclogae geol. Helv. 89(1), 389-425.

Müntener, O. and Hermann, J. 2001. The role of lower crust and continental upper mantle during formation of non volcanic passive margins: evidence from the Alps. In: R.C.L. Wilson, R.B. Whitmarsh, B. Taylor and N. Froitzheim (Eds.), Nonvolcanic rifting of continental margins: a comparison of evidence from land and sea. Geological Soc. Spec. Publ. 187, 267-288

Odin, G.S. 1994. Geological time scale. Comptes Rendus de l'Académie des Sciences de Paris, Série II. 318, 59-71.

Peybernès, B. 1976. Le Jurassique et le Crétacé inférieur des Pyrénées franco-espagnoles. Thèse 696 Thesis, Uni. PaulSabatier, Toulouse.

Peybernès, B. and Souquet, P. 1984. Basement blocks and tectosedimentary evolution in the Pyrenees during Mesozoic times. Geological Magazine. 121(5), 397-405.

Puga, E., Diaz de Federico, A. and Demant, A. 1995. The eclogitized pillows of the Betic Ophiolitic Asoociation: relics of the Tethys Ocean floor incorporated in the Alpine chain after subduction. Terra Nova. 7(1), 31-43.

Python-Dupasquier, C. 1990. La formation de l'Intyamon ("Crétacé moyen") des Préalpes médianes romandes. Thèse 978 Thesis, Uni. Fribourg.

Rampone, E. and Piccardo, G. 2000. The ophiolite-oceanic lithosphere analogue:new insights from the northern Apennines (Italy). In: Y. Dilek, E.M. Moores, D. Elthon and A. Nicolas (Eds.), Ophiolites and oceanic crust:new insights from field studies and the ocean drilling project. Geol. Soc. America Spec. Paper 349, 21-34.

Roca, E. 2001. The Northwest Mediterranean Basin (Valencia trough, Gulf of Lions and Liguro-Provençal baisns): structure and geodynamic evolution. In: P.A. Ziegler, W. Cavazza, A.H.F. Robertson and S. Crasquin-Soleau (Eds.), PeriTethys memoir 6: Peritethyan rift/wrench basins and passive margins, IGCP 369. Mém. Museum Nat. Hist. Nat Paris 186, 671-706.

Schmid, S., Zingg, A. and Handy, M. 1987. The kinematics of movements along the Insubric Line and the emplacement of the Ivrea Zone. Tectonophysics. 135, 47-66.

Schmid, S.M., Rück, P. and Schreurs, G. 1990. The significance of the Schams nappe for the reconstruction of the paleotectonic and orogenic evolution of the Penninic zone along the NFP-20 East traverse (Grisons, eastern Switzerland). In: F.
Roure, P. Heitzmann and R. Polino (Eds.), Deep structures of the Alps. Mém. Soc. géol. France 156; Mém. Soc. géol. Suisse, 1; Vol. spec. Soc. It.,1, 263-288.

Septfontaine, M. 1983. Le dogger des préalpes médianes suisses et francaises: stratigraphie, évolution paléogéographique et paléotectonique. Mémoires de la Société Helvétique des Sciences Naturelles. 97, 1-121.

Sibuet, J.-C. and Colette, B.J. 1991. Triple junctions of Bay of Biscay and North Atlantic: new constraints on the kinematic evolution. Geology. 19, 522-525.

Sibuet, J.C. and Collette, B.J. 1991. Triple junctions of Bay of Biscay and North Atlantic: New constrains on the kinematic evolution. Geology. 19(5), 522-525.

Simo, A. 1986. Carbonate platform depositional sequences, upper Cretaceous, South-central Pyrenees (Spain). Tectonophysics. 129, 205-231.

Sommaruga, A. 1999. Décollement tectonics in the Jura foreland fold and thrust belt. Marine \& Petrol. geol. 16, 111-134.

Spring, L., Reymond, B., Masson, H. and Steck, A. 1992. La nappe du Lebendun entre Alte Kaserne et le Val Cairasca (massif du Simplon); nouvelles observations et interprétations. Eclogae geologicae Helvetiae. 85(1), 85-104.

Srivastava, S.P. et al. 1990. Motion of Iberia since the Late Jurassic: results from detailed aeromagnetic measurements in the Newfoundland Basin. Tectonophysics. 184, 229-260.

Srivastava, S.P. and Verhoef, J. 1992. Evolution of Mesozoic sedimentary basins around the North Central Atlantic: a preliminary plate kinematic solution. In: J. Parnell (Ed.), Basins on the Atlantic Seabord. Geol. Soc. London Spec. Publ. 62, 397-420.

Stampfli, G.M. 1993. Le Briançonnais, terrain exotique dans les Alpes? Eclogae geologicae Helvetiae. 86(1), 1-45.

Stampfli, G.M. 1996. The Intra-Alpine terrain: a Paleotethyan remnant in the Alpine Variscides. Eclogae geol. Helv. 89(1), 13-42.

Stampfli, G.M. 2000. Tethyan oceans. In: E. Bozkurt, J.A. Winchester and J.D.A. Piper (Eds.), Tectonics and magmatism in Turkey and surrounding area. Geological Society of London, Special Publication 173, 163-185.

Stampfli, G.M. (Ed.), 2001. Geology of the western Swiss Alps, a guide book. Mémoires de Géologie (Lausanne) 36, 195 p.

Stampfli, G.M. and Marchant, R.H. 1995. Plate configuration and kinematics in the Alpine region. Accademia Nazionale delle Scienze, Scritti e Documenti. 14(Atti del congresso "Rapporti tra Alpi e Appennino"), 147-166.

Stampfli, G.M. and Borel, G. 2000. West-Tethys oceans, Geology 2000 Geol Ver. 90th meet. Terra nostra Schr. Alf. Weg. St., Vienna, 113.

Stampfli, G.M., Borel, G., Cavazza, W., Mosar, J. and Ziegler, P.A. (Eds.) 2001a. The paleotectonic atlas of the Peritethyan domain. CD ROM; European Geophysical Society p.

Stampfli, G.M., Borel, G., Cavazza, W., Mosar, J. and Ziegler, P.A. 2001b. The paleotectonic atlas of the Peritethyan domain on CD ROM - A presentation, EGS 26th General assembly. Geophysical research abstracts, Nice, GRA3, 878.

Stampfli, G.M. and Borel, G.D. 2002. A plate tectonic model for the Paleozoic and Mesozoic constrained by dynamic plate boundaries and restored synthetic oceanic isochrons. Earth and Planetary Science Letters, in press

Stampfli, G.M. and Marchant, R.H. 1995. Plate configuration 
and kinematics in the Alpine region. Accademia Nazionale delle Scienze, Scritti e Documenti. 14(Atti del congresso "Rapporti tra Alpi e Appennino"), 147-166.

Stampfli, G.M., Marcoux, J. and Baud, A. 1991. Tethyan margins in space and time. In: J.E.T. Channell, E.L. Winterer and L.F. Jansa (Eds.), Paleogeography and paleoceanography of Tethys. Palaeogeography, Palaeoclimatology, Palaeoecology. Palaeogeography, Palaeoclimatology, Palaeoecology 87, 373-410.

Stampfli, G.M., Mosar, J., Favre, P., Pillevuit, A. and Vannay, J.C. 2001c. Permo-Mesozoic evolution of the western Tethyan realm: the Neotethys/East- Mediterranean connection. In: P.A. Ziegler, W. Cavazza, A.H.F. Robertson and S. CrasquinSoleau (Eds.), PeriTethys memoir 6: Peritethyan rift/wrench basins and passive margins, IGCP 369. Mém. Museum Nat. Hist. Nat Paris 186, 51-108.

Stampfli, G.M. et al. 1998. Subduction and obduction processes in the western Alps. In: A. Vauchez and R. Meissner (Eds.), Continents and their mantle roots. Tectonophysics 296(1-2), 159-204.

Stampfli, G.M. and Pillevuit, A. 1993. An alternative PermoTriassic reconstruction of the kinematics of the Tethyan realm. In: J. Dercourt, L.-E. Ricou and B. Vrielinck (Eds.), Atlas Tethys Palaeoenvironmental Maps. Explanatory Notes. Gauthier-Villars Paris, 55-62.

Stampfli, G.M. et al. 2002a. Remnants of the Paleotethys oceanic suture-zone in the western Tethyan area. Bolletino della Società Geologica Italiana, in press.

Stampfli, G.M., von Raumer, J. and Borel, G.D. 2002b. The Palaeozoic evolution of pre-Variscan terranes: From periGondwana to the Variscan collision. In: J.R. MartinezCatalan, R.D. Hatcher, R. Arenas and F. Diaz Garcia (Eds.), Variscan Appalachian Dynamics: the building of the Upper Paleozoic basement. Geological Society of America Special Paper in press, in press.

Steck, A., Epard, J.-L., Escher, A., Marchant, R. and Masson, H. 1997. Geologic interpretation of the seismic profiles through western Switzerland: Rawil (W1), Val d'Anniviers (W2), Mattertal (W3), Zmutt-Zermatt-Findelen (W4) and Val de Bagnes (W5). In: O.A. Pfiffner, P. Lehner, P.Z. Heitzman, S. Mueller and A. Steck (Eds.), Deep structure of the Swiss Alps - Results from NRP 20. Birkhaüser AG. Basel, 123-138.

Steck, A. et al. 1989. Coupe tectonique horizontale des Alpes centrales. Mémoires de Géologie (Lausanne). 5, 8.

Steck, A. and Hunziker, J. 1994. The Tertiary structural and thermal evolution of the Central Alps - compressional and extensional structures in an orogenic belt. Tectonophysics. 238, 229-254.

Steffen, D., Jaques, C., Nydegger, T., Petroons, D. and Wildi, W. 1993. La Brèche du Chablais à son extremité occidentale (Haute-Savoie, France): sédimentologie, éléments stratigraphiques et interprétation paléogéographique. Eclogae geologicae Helvetiae. 86(2), 543-568.

Steiner, C.W., Hobson, A., Favre, P., Stampfli, G.M. and Hernandez, J. 1998. The Mesozoic sequence of Fuerteventura (Canary islands): witness of an Early to Middle Jurassic sea-floor spreading in the Central Atlantic.
Geol. Soc. Amer. Bull. 110(10), 1304-1317.

Thurow, J. 1987. Die kretazischen Turbiditserien im Gibraltarbogen: Bindeglied zwischen atlantischer und tethyaler Entwicklung. Ph.D. Thesis Thesis, Tübingen.

Toury, A. 1985. Etude géologique de la Vallée de la Valloirette entre Valloire, le Col du Galibier et les Aiguilles d'Arves (Alpes occidentales - Savoie), Savoie University, Chambéry.

Trümpy, R. 1992. Ostalpen und Westalpen-Verbindendes und Trennendes. Jb. Geol. B.-A. 135(4), 875-882.

Vavassis, I. 2001. Geology and Paleogeographic Evolution of the Pelagonian zone in Northern Evia Island, Greece. Constraints and geodynamic implications for the Hellenides. Ph.D. Thesis Thesis, University of Lausanne, Lausanne, Switzerland

Vavassis, I. De Bono A., Stampfli G. M., Giorgis D., Valloton A.and Amelin Y., 2000. U-Pb and Ar-Ar geochronological data from the Pelagonian basement in Evia (Greece): geodynamic implications for the evolution of Paleotethys. Schweizerische Mineralogische und Petrographische Mitteilungen. 80, 21-43.

Venturini, G. 1995. Geology, geochemistry and geochronology of the inner central Sesia Zone (Western Alps - Italy). Mémoires de Géologie (Lausanne). 25, 183.

Vergés, J. and Garcia-Senz, J. 2001. Mesozoic evolution and Cainozoic inversion of the Pyrenean Rift. In: P.A. Ziegler, W. Cavazza, A.H.F. Robertson and S. Crasquin-Soleau (Eds.), PeriTethys memoir 6: Peritethyan rift/wrench basins and passive margins, IGCP 369. Mém. Museum Nat. Hist. Nat Paris $186,187-212$

von Raumer, J., Stampfli, G.M., Borel, G.D. and Bussy, F. 2002. The organisation of pre-Variscan basement areas at the northGondwanan margin. International Journal of Earth Sciences. 91, in press.

Wildi, W. 1983. La chaîne tello-rifaine (Algérie, Maroc, Tunisie) structure, stratigraphie et évolution du Trias au Miocène. Revue de Géographie Physique et de Géologie Dynamique. 24(3), 201-297.

Winterer, E.L. and Bosellini, A. 1981. Subsidence and sedimentation on Jurassic passive continental margin, southern Alps, Italy. American Association of Petroleum Geologists Bulletin. 65(3), 394-417.

Wortel, M.J.R. and Spakman, W. 1992. Structure and dynamics of subducted lithosphere in the Mediterranean region. Proceedings of the koninklijke nederlandse Akademie van Wetenschappen. Series B: Palaeontology, Geology, Physics, Chemistry, Anthropology. 95(3), 325-347.

Ziegler, P.A. and Stampfli, G.M. 2001. Late Paleozoic Early Mesozoic plate boundary reorganisation: collapse of the Variscan orogen and opening of Neotethys. In: R. Cassinis (Ed.), the continental Permian of the Southern Alps and Sardinia (Italy) regional reports and general correlations. Annali Museo Civico Science Naturali, Brescia Brescia 25, 17-34.

Zingg, A., Handy, M.R., Hunziker, J.C. and Schmid, S.M. 1990. Tectonometamorphic history of the Ivrea zone and its relationships to the crustal evolution of the Southern Alps. Tectonophysics. 182, 169-192. 